Nevada

Environmental Management

Operations Activity

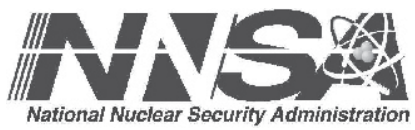

Closure Report for Corrective Action Unit 548:

Areas 9, 10, 18, 19, and 20 Housekeeping Sites, Nevada National Security Site, Nevada

Controlled Copy No::

Revision: 0

August 2012 


\section{DISCLAIMER}

Reference herein to any specific commercial product, process, or service by trade name, trademark, manufacturer, or otherwise, does not necessarily constitute or imply its endorsement, recommendation, or favoring by the United States Government or any agency thereof.

This report has been reproduced directly from the best available copy.

Available for sale to the public from:

U.S. Department of Commerce

National Technical Information Service

5301 Shawnee Road

Alexandria, VA 22312

Telephone: (800) 553-6847

Fax: (703) 605-6900

E-mail: orders@ntis.gov

Online ordering: http://www.ntis.gov/help/ordermethods.aspx

Available electronically at http://www.osti.gov/bridge.

Available for a processing fee to the U.S. Department of Energy and its contractors, in paper, from:

U.S. Department of Energy

Office of Scientific and Technical Information

P.O. Box 62

Oak Ridge, TN 37831-0062

Telephone: (865) 576-8401

Fax: (865) 576-5728

E-mail: reports@adonis.osti.gov 


\title{
CLOSURE REPORT FOR CORRECTIVE ACTION UNIT 548: \\ AREAS 9, 10, 18, 19, AND 20 HOUSEKEEPING SITES, NEVADA NATIONAL SECURITY SITE, NEVADA
}

\author{
U.S. Department of Energy \\ National Nuclear Security Administration \\ Nevada Site Office \\ Las Vegas, Nevada
}

Controlled Copy No.

Revision: 0

August 2012 
THIS PAGE INTENTIONALLY LEFT BLANK 


\section{CLOSURE REPORT FOR CORRECTIVE ACTION UNIT 548: AREAS 9, 10, 18, 19, AND 20 HOUSEKEEPING SITES, NEVADA NATIONAL SECURITY SITE, NEVADA}

\footnotetext{
Approved By: /s/: Tiffany A. Lantow Tiffany A. Lantow

Date: $8 / 6 / 2012$ Industrial Sites Activity Lead

Approved By:

/s/: Robert F. Boehlecke

R̄obert F. Boehlecke

Date:

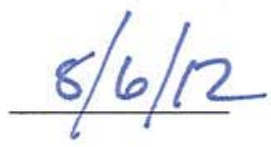

Environmental Management Operations Activity Manager
} 
THIS PAGE INTENTIONALLY LEFT BLANK 


\section{TABLE OF CONTENTS}

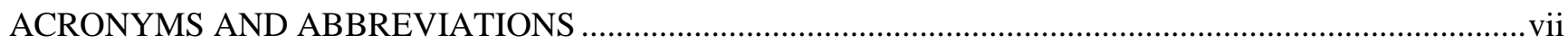

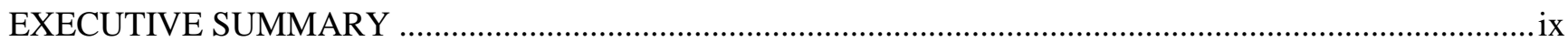

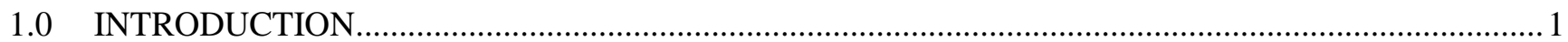

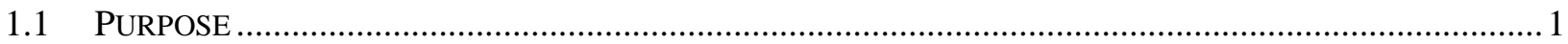

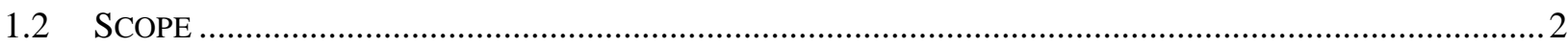

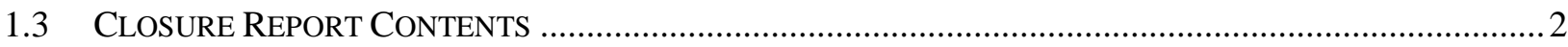

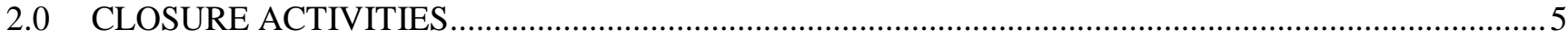

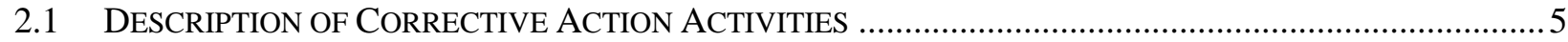

2.1.1 Corrective Action Site 09-99-02, Material Piles (2) ......................................................... 5

2.1.2 Corrective Action Site 09-99-04, Wax, Paraffin ................................................................ 5

2.1.3 Corrective Action Site 09-99-05, Asbestos, Vermiculite .................................................... 5

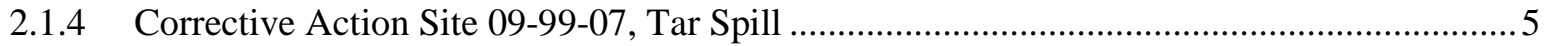

2.1.5 Corrective Action Site 10-22-02, Drums......................................................................... 5

2.1.6 Corrective Action Site 10-22-05, Gas Block...............................................................

2.1.7 Corrective Action Site 10-22-07, Gas Block.............................................................. 5

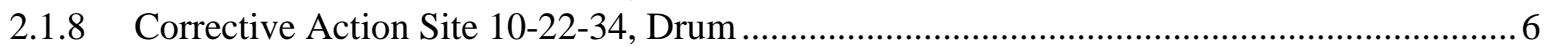

2.1.9 Corrective Action Site 10-22-38, Drum; Cable................................................................... 6

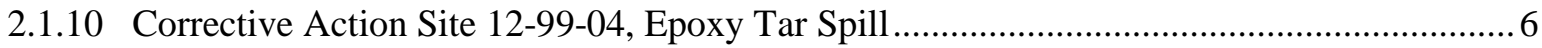

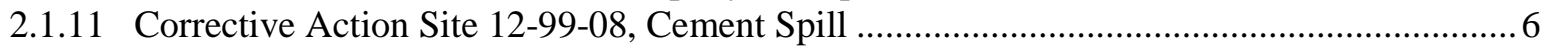

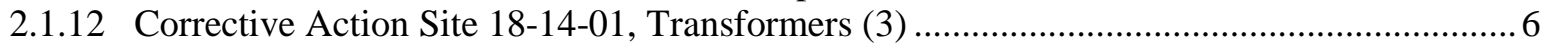

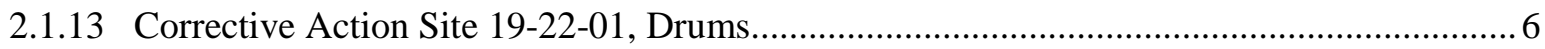

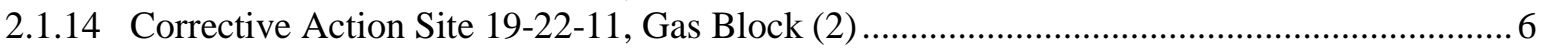

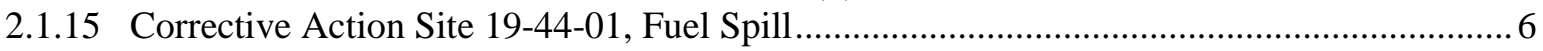

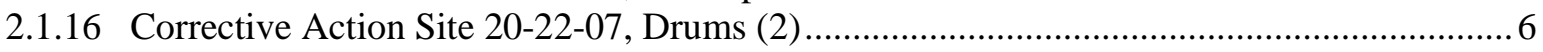

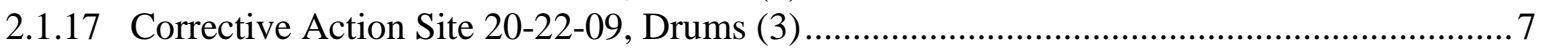

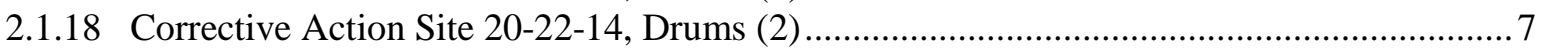

2.1.19 Corrective Action Site 20-22-16, Drums (2) ................................................................. 7

2.1.20 Corrective Action Site 20-24-09, Battery................................................................. 7

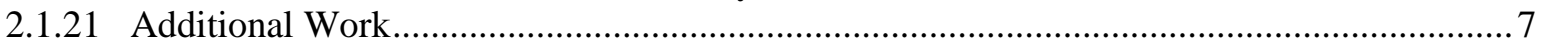

2.1.21.1 Area 9 Burn Pile .................................................................................... 7

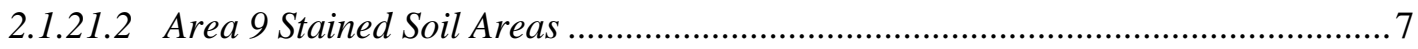

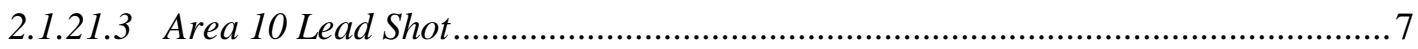

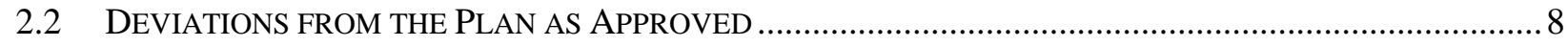

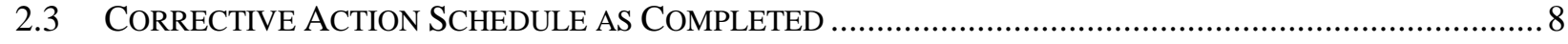

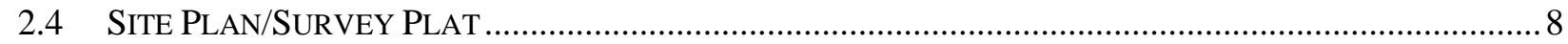

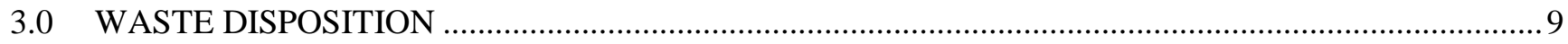

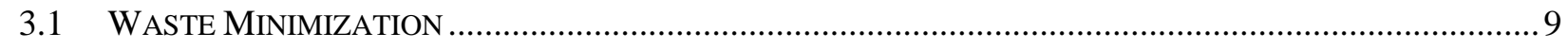

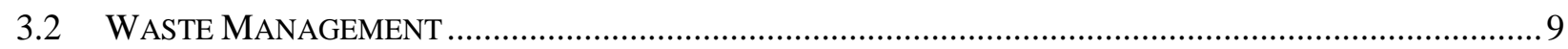

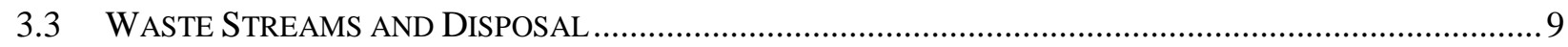

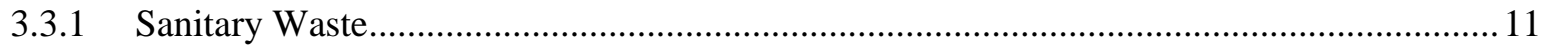

3.3.2 Hydrocarbon Waste................................................................................................ 11

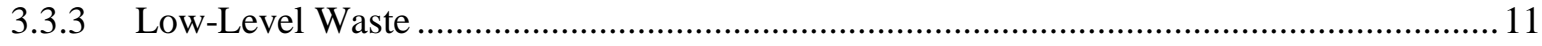

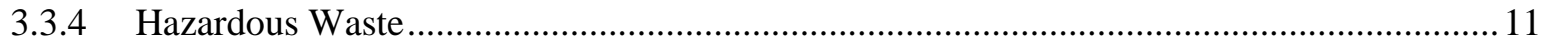

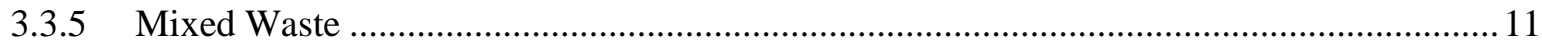




\section{TABLE OF CONTENTS (continued)}

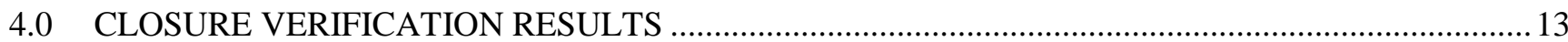

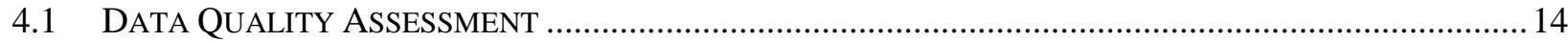

4.1.1 Quality Assurance and Quality Control Procedures......................................................... 14

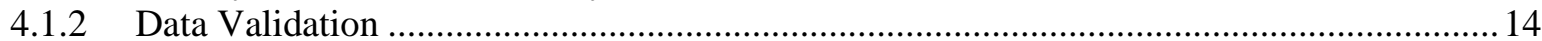

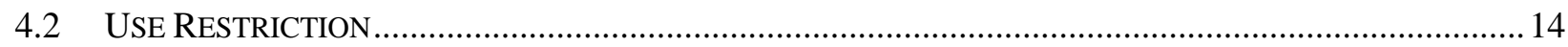

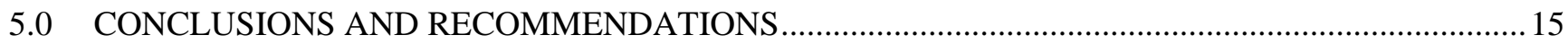

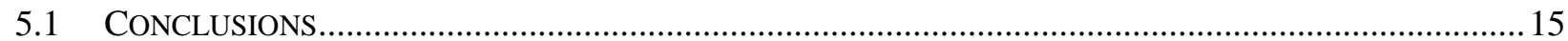

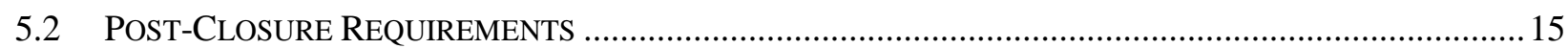

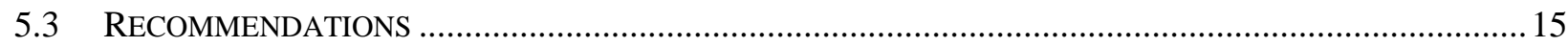

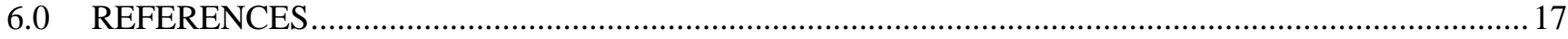

LIBRARY DISTRIBUTION LIST

\section{LIST OF TABLES}

TABle 1. Summary of Corrective Action Unit 548 Closure Activities ......................................3

TABle 2. Corrective Action Unit 548 Closure Activities SCHEdUle .........................................8

Table 3. Corrective Action Unit 548 Waste Disposition Summary ..........................................10

Table 4. Verification SAmple Results Detected Above Minimum Detectable CONCENTRATIONS FOR CORRECTIVE ACTION SITE 09-99-04 ...........................................13

Table 5. Verification Sample Results Detected Above Minimum Detectable CONCENTRATIONS FOR CORRECTIVE ACTION SITE 09-99-05 .13

Table 6. Verification SAmple Results Detected Above Minimum Detectable CONCENTRATIONS FOR THE AREA 9 First StAinED SOIL AREA.

\section{APPENDICES}

ApPEndiX A. SAmple AnAlytical Results

APPENDIX B. WASTE DISPOSITION DOCUMENTATION

ApPENDix C. SECTORED HOUSEKEEPING Site ClOSURE VERIFICATION FORMS 


\section{ACRONYMS AND ABBREVIATIONS}

\begin{tabular}{|c|c|}
\hline CA & Contamination Area \\
\hline CAS & Corrective Action Site \\
\hline CAU & Corrective Action Unit \\
\hline CR & Closure Report \\
\hline DOE & U.S. Department of Energy \\
\hline EPA & U.S. Environmental Protection Agency \\
\hline FFACO & Federal Facility Agreement and Consent Order \\
\hline gal & gallon(s) \\
\hline $\mathrm{HW}$ & hazardous waste \\
\hline LLW & low-level waste \\
\hline $\mathrm{mg} / \mathrm{kg}$ & milligram(s) per kilogram \\
\hline MW & mixed waste \\
\hline NCRP & National Council on Radiation Protection and Measurements \\
\hline NNSA/NSO & $\begin{array}{l}\text { U.S. Department of Energy, National Nuclear Security Administration Nevada } \\
\text { Site Office }\end{array}$ \\
\hline NNSA/NV & $\begin{array}{l}\text { U.S. Department of Energy, National Nuclear Security Administration Nevada } \\
\text { Operations Office }\end{array}$ \\
\hline NNSS & Nevada National Security Site \\
\hline $\mathrm{pCi} / \mathrm{g}$ & picocurie(s) per gram \\
\hline PPE & personal protective equipment \\
\hline $\mathrm{Pu}$ & plutonium \\
\hline QA & quality assurance \\
\hline QAPP & Industrial Sites Quality Assurance Project Plan \\
\hline QC & quality control \\
\hline RMA & Radioactive Material Area \\
\hline RWMS & Radioactive Waste Management Site \\
\hline $\mathrm{TPH}$ & total petroleum hydrocarbons \\
\hline WMA & waste management area \\
\hline $\mathrm{yd}^{3}$ & cubic yard(s) \\
\hline
\end{tabular}


CAU 548 Closure Report

Section: Acronyms and Abbreviations

Revision: 0

Date: August 2012

\section{THIS PAGE INTENTIONALLY LEFT BLANK}




\section{EXECUTIVE SUMMARY}

This Closure Report (CR) documents closure activities for Corrective Action Unit (CAU) 548, Areas 9, 10, 18, 19, and 20 Housekeeping Sites, and complies with the Federal Facility Agreement and Consent Order (FFACO) that was agreed to by the State of Nevada; the U.S. Department of Energy (DOE), Environmental Management; the U.S. Department of Defense; and DOE, Legacy Management (FFACO, 1996 as amended). CAU 548 consists of the following Corrective Action Sites (CASs), located in Areas 9, 10, 12, 18, 19, and 20 of the Nevada National Security Site:

- CAS 09-99-02, Material Piles (2)

- CAS 09-99-04, Wax, Paraffin

- CAS 09-99-05, Asbestos, Vermiculite

- CAS 09-99-07, Tar Spill

- CAS 10-22-02, Drums

- CAS 10-22-05, Gas Block

- CAS 10-22-07, Gas Block

- CAS 10-22-34, Drum

- CAS 10-22-38, Drum; Cable

- CAS 12-99-04, Epoxy Tar Spill

- CAS 12-99-08, Cement Spill

- CAS 18-14-01, Transformers (3)

- CAS 19-22-01, Drums

- CAS 19-22-11, Gas Block (2)

- CAS 19-44-01, Fuel Spill

- CAS 20-22-07, Drums (2)

- CAS 20-22-09, Drums (3)

- CAS 20-22-14, Drums (2)

- CAS 20-22-16, Drums (2)

- CAS 20-24-09, Battery

Closure activities began in July 2011 and were completed in December 2011 and included removal and disposal of material piles, spills, sanitary debris, a lead acid battery, lead and steel shot, and stained soil. Activities were conducted according to the Sectored Clean-up Work Plan for Housekeeping Category Waste Sites (U.S. Department of Energy, National Nuclear Security Administration Nevada Site Office [NNSA/NSO], 2003).

Closure activities generated sanitary waste, hydrocarbon waste, low-level waste, hazardous waste, and mixed waste. Some wastes exceeded land disposal limits and required offsite treatment prior to disposal. Other wastes met land disposal restrictions and were disposed in appropriate onsite or offsite landfills. 
NNSA/NSO requests the following:

- A Notice of Completion from the Nevada Division of Environmental Protection to NNSA/NSO for closure of CAU 548

- The transfer of CAU 548 from Appendix III to Appendix IV, Closed Corrective Action Units, of the FFACO 


\subsection{INTRODUCTION}

This Closure Report (CR) documents closure activities for Corrective Action Unit (CAU) 548, Areas 9, 10, 18, 19, and 20 Housekeeping Sites, according to the Federal Facility Agreement and Consent Order (FFACO) that was agreed to by the State of Nevada; the U.S. Department of Energy (DOE), Environmental Management; the U.S. Department of Defense; and DOE, Legacy Management (FFACO, 1996 as amended). CAU 548 consists of the following Corrective Action Sites (CASs), located in Areas 9, 10, 12, 18, 19, and 20 of the Nevada National Security Site (NNSS):

- CAS 09-99-02, Material Piles (2)

- CAS 09-99-04, Wax, Paraffin

- CAS 09-99-05, Asbestos, Vermiculite

- CAS 09-99-07, Tar Spill

- CAS 10-22-02, Drums

- CAS 10-22-05, Gas Block

- CAS 10-22-07, Gas Block

- CAS 10-22-34, Drum

- CAS 10-22-38, Drum; Cable

- CAS 12-99-04, Epoxy Tar Spill

- CAS 12-99-08, Cement Spill

- CAS 18-14-01, Transformers (3)

- CAS 19-22-01, Drums

- CAS 19-22-11, Gas Block (2)

- CAS 19-44-01, Fuel Spill

- CAS 20-22-07, Drums (2)

- CAS 20-22-09, Drums (3)

- CAS 20-22-14, Drums (2)

- CAS 20-22-16, Drums (2)

- CAS 20-24-09, Battery

\subsection{Purpose}

This CR provides justification for closure of CAU 548 without further corrective action based on implementation of corrective actions in accordance with the Sectored Clean-up Work Plan for Housekeeping Category Waste Sites (U.S. Department of Energy, National Nuclear Security Administration Nevada Site Office [NNSA/NSO], 2003). This CR provides a summary of completed closure activities, documentation supporting the completed corrective actions, and confirmation that the closure objectives were met. 


\subsection{SCOPE}

The scope of closure for CAU 548 included removal and disposal of material piles, spills, sanitary debris, a lead acid battery, lead and steel shot, and stained soil. Closure activities are summarized in Table 1.

\subsection{Closure Report Contents}

This CR includes the following sections:

- Section 1.0: Introduction

- Section 2.0: Closure Activities

- Section 3.0: Waste Disposition

- Section 4.0: Closure Verification Results

- Section 5.0: Conclusions and Recommendations

- Section 6.0: References

- Appendix A: Sample Analytical Results

- Appendix B: Waste Disposition Documentation

- Appendix C: Sectored Housekeeping Site Closure Verification Forms

- Library Distribution List 
TABle 1. Summary of Corrective ACtion Unit 548 Closure Activities

\begin{tabular}{|c|c|c|}
\hline CAS & $\begin{array}{l}\text { CAS NAME OR } \\
\text { SITE DESCRIPTION }\end{array}$ & Closure ACTIVITIES \\
\hline 09-99-02 & Material Piles (2) & A material pile was removed and disposed at the Area 9 U10c Sanitary Landfill. \\
\hline 09-99-04 & Wax, Paraffin & $\begin{array}{l}\text { A material pile was removed, packaged in nine B-25 boxes, treated by an offsite treatment facility, and will be } \\
\text { returned to the NNSS for disposal as MW at the Area } 5 \text { RWMS. A verification sample was collected and analyzed } \\
\text { for the hazardous constituents of TPH, total chromium, and isotopic Pu. }\end{array}$ \\
\hline 09-99-05 & Asbestos, Vermiculite & $\begin{array}{l}\text { A material pile was removed, packaged in one B-25 box, and disposed as LLW at the Area } 5 \text { RWMS. A verification } \\
\text { sample was collected and analyzed for the hazardous constituents of TPH. }\end{array}$ \\
\hline 09-99-07 & Tar Spill & A tar spill was removed and disposed at the Area 9 U10c Sanitary Landfill. \\
\hline $10-22-02$ & Drums & None \\
\hline $10-22-05$ & Gas Block & None \\
\hline $10-22-07$ & Gas Block & None \\
\hline $10-22-34$ & Drum & None \\
\hline $10-22-38$ & Drum; Cable & $\begin{array}{l}\text { A 55-gal gas block drum, a small can, and wooden debris were removed and disposed at the Area } 9 \text { U10c Sanitary } \\
\text { Landfill. }\end{array}$ \\
\hline $12-99-04$ & Epoxy Tar Spill & None \\
\hline $12-99-08$ & Cement Spill & Cement and asphalt piles were removed and disposed at the Area 9 U10c Sanitary Landfill. \\
\hline $18-14-01$ & Transformers (3) & None \\
\hline $19-22-01$ & Drums & None \\
\hline $19-22-11$ & Gas Block (2) & None \\
\hline $19-44-01$ & Fuel Spill & None \\
\hline $20-22-07$ & Drums (2) & $\begin{array}{l}\text { Seven abandoned, empty 55-gal drums were removed and disposed at the Area } 9 \text { U10c Sanitary Landfill. One lead } \\
\text { acid battery was removed, packaged in a 55-gal drum, treated at an offsite treatment facility, and will be returned to } \\
\text { the NNSS for disposal as MW at the Area } 5 \text { RWMS. Tires were removed, packaged in one B-25 box, and disposed at } \\
\text { the Area } 9 \text { U10c Sanitary Landfill. }\end{array}$ \\
\hline $20-22-09$ & Drums (3) & None \\
\hline
\end{tabular}


Table 1. Summary of Corrective Action Unit 548 Closure Activities (Continued)

\begin{tabular}{|c|c|l||}
\hline CAS & $\begin{array}{c}\text { CAS NAME OR } \\
\text { SITE DESCRIPTION }\end{array}$ & \multicolumn{1}{c|}{ CLOSURE ACTIVITIES } \\
\hline \hline $20-22-14$ & Drums (2) & None \\
\hline $20-22-16$ & Drums (2) & None \\
\hline $20-24-09$ & Battery & None \\
\hline $\begin{array}{c}\text { No CAS } \\
\text { Number }\end{array}$ & Area 9 Burn Pile & A burn pile was removed and disposed as hydrocarbon waste at the Area 9 U10c Sanitary Landfill. \\
\hline $\begin{array}{c}\text { No CAS } \\
\text { Number }\end{array}$ & $\begin{array}{c}\text { Area 9 Stained Soil } \\
\text { Areas }\end{array}$ & $\begin{array}{l}\text { Stained soil was removed from two areas, packaged in nine B-25 boxes, and disposed as LLW at the Area 5 RWMS. } \\
\text { A verification sample was collected and analyzed for chromium. }\end{array}$ \\
\hline $\begin{array}{c}\text { No CAS } \\
\text { Number }\end{array}$ & Area 10 Lead Shot & $\begin{array}{l}\text { Lead and steel shot and associated soil were removed, packaged in five 55-gal drums, and treated and disposed as } \\
\text { HW at an offsite facility. }\end{array}$ \\
\hline
\end{tabular}

CAS: Corrective Action Site

gal: gallon(s)

HW: hazardous waste

LLW: low-level waste

MW: mixed waste

NNSS: Nevada National Security Site

Pu: plutonium

RWMS: Radioactive Waste Management Site

TPH: total petroleum hydrocarbons 


\subsection{CLOSURE ACTIVITIES}

This section describes the closure activities performed for CAU 548. Copies of the Sectored Housekeeping Site Closure Verification Forms are included in Appendix C. These forms include before and after photographs of the sites, descriptions of waste, and waste disposal information.

\subsection{Description of CoRrective ACtion Activities}

The following sections describe the closure activities completed for each CAS in CAU 548.

\subsubsection{Corrective Action Site 09-99-02, Material Piles (2)}

At CAS 09-99-02, a material pile was removed and disposed at the Area 9 U10c Sanitary Landfill.

\subsubsection{Corrective Action Site 09-99-04, Wax, Paraffin}

At CAS 09-99-04, a material pile and soil was removed, packaged in nine B-25 boxes, and treated at an offsite treatment facility. The waste was returned to the NNSS for disposal as mixed waste (MW) at the Area 5 Radioactive Waste Management Site (RWMS). A verification sample was collected from the bottom of the excavation and analyzed for the hazardous constituents of total petroleum hydrocarbons (TPH), total chromium, and isotopic plutonium (Pu). The excavation was backfilled.

\subsubsection{Corrective Action Site 09-99-05, Asbestos, Vermiculite}

At CAS 09-99-05, a material pile was removed, packaged in one B-25 box, and disposed as low-level waste (LLW) at the Area 5 RWMS. A verification sample was collected from the underlying soil and analyzed for the hazardous constituents of TPH. Although the material exceeded the landfill acceptance criteria for radiological constituents, radionuclides did not exceed action levels; therefore, the verification sample was not analyzed for radionuclides.

\subsubsection{Corrective Action Site 09-99-07, Tar Spill}

At CAS 09-99-07, a tar spill was removed and disposed at the Area 9 U10c Sanitary Landfill.

\subsubsection{Corrective Action Site 10-22-02, Drums}

At CAS 10-22-02, a crater stability study was performed that indicated the crater is unstable; therefore, no closure activities were performed.

\subsubsection{Corrective Action Site 10-22-05, Gas Block}

At CAS 10-22-05, a crater stability study was performed that indicated the crater is unstable; therefore, no closure activities were performed.

\subsubsection{Corrective Action Site 10-22-07, Gas Block}

At CAS 10-22-07, a crater stability study was performed that indicated the crater is unstable; therefore, no closure activities were performed. 


\subsubsection{Corrective Action Site 10-22-34, Drum}

At CAS 10-22-34, a crater stability study was performed that indicated the crater is unstable; therefore, no closure activities were performed.

\subsubsection{Corrective Action Site 10-22-38, Drum; Cable}

At CAS 10-22-38, a 55-gallon (gal) gas block drum, a small can, and wooden debris were removed and disposed at the Area 9 U10c Sanitary Landfill.

\subsubsection{Corrective Action Site 12-99-04, Epoxy Tar Spill}

At CAS 12-99-04, the spill originally described at the site was determined to be a deteriorated 200-foot-long drainage channel constructed to control water flow from a concrete pad. Due to the absence of contamination and the inability of heavy equipment to access the area, no further action was required, and no closure activities were performed.

\subsubsection{Corrective Action Site 12-99-08, Cement Spill}

At CAS 12-99-08, cement and asphalt piles were removed and disposed at the Area 9 U10c Sanitary Landfill.

\subsubsection{Corrective Action Site 18-14-01, Transformers (3)}

At CAS 18-14-01, three junction boxes containing wires were found. Transformers were not located at this site. No further action was required, and no closure activities were performed.

\subsubsection{Corrective Action Site 19-22-01, Drums}

At CAS 19-22-01, the drums previously located at the site were not found and are assumed to have been removed. No further action was required, and no closure activities were performed.

\subsubsection{Corrective Action Site 19-22-11, Gas Block (2)}

At CAS 19-22-11, a crater stability study was performed that indicated the crater is unstable; therefore, no closure activities were performed.

\subsubsection{Corrective Action Site 19-44-01, Fuel Spill}

At CAS 19-44-01, a crater stability study was performed that indicated the crater is unstable; therefore, no closure activities were performed.

\subsubsection{Corrective Action Site 20-22-07, Drums (2)}

At CAS 20-22-07, seven abandoned, empty 55-gal drums were removed from the Contamination Area (CA) and disposed at the Area 9 U10c Sanitary Landfill. Tires were removed from the CA, packaged in one B-25 box, and disposed at the Area 9 U10c Sanitary Landfill. One lead acid battery was removed from the CA, packaged in a 55-gal drum, and treated on site. The waste was disposed as MW at the Area 5 RWMS. Personal protective equipment (PPE) used during entry into the CA was packaged in a 55-gal drum and disposed as LLW at the Area 5 RWMS. 


\subsubsection{Corrective Action Site 20-22-09, Drums (3)}

At CAS 20-22-09, a crater stability study was performed that indicated the crater is unstable; therefore, no closure activities were performed.

\subsubsection{Corrective Action Site 20-22-14, Drums (2)}

At CAS 20-22-14, a crater stability study was performed that indicated the crater is unstable; therefore, no closure activities were performed.

\subsubsection{Corrective Action Site 20-22-16, Drums (2)}

At CAS 20-22-16, a crater stability study was performed that indicated the crater is unstable; therefore, no closure activities were performed.

\subsubsection{Corrective Action Site 20-24-09, Battery}

At CAS 20-24-09, a crater stability study was performed that indicated the crater is unstable; therefore, no closure activities were performed.

\subsubsection{Additional Work}

Additional closure activities were conducted in several locations near the CAU 548 sites. These activities are described below.

\subsubsection{Area 9 Burn Pile}

A burn pile in Area 9 was removed and disposed as hydrocarbon waste at the Area 9 U10c Sanitary Landfill.

\subsubsection{Area 9 Stained Soil Areas}

Two stained soil areas were identified near the burn pile in Area 9. Chromium and Pu-239 were present at concentrations above action levels in characterization samples collected from the first stained soil area. Pu-239 was present at concentrations above the action level in characterization samples from the second stained soil area. Because the sites are located within the investigation area of CAU 570, a Soils site, the radiological contamination will be addressed under the closure of CAU 570. Therefore, Pu-239 is not considered a contaminant of concern for CAU 548.

Stained soil was removed from the first stained soil area and packaged in three B-25 boxes. A verification sample was collected from the bottom of the excavation and analyzed for chromium. Stained soil was removed from the second stained area as a best management practice and packaged in six B-25 boxes. Verification samples were not collected after excavation of the second stained soil area because no contaminants of concern were present. The waste was below the landfill acceptance criteria for chromium; therefore, it was disposed as LLW at the Area 5 RWMS. The excavations were backfilled.

\subsubsection{Area 10 Lead Shot}

In Area 10, lead and steel shot and associated soil were removed, packaged in five 55-gal drums, and treated and disposed as hazardous waste (HW) at an offsite facility. 


\subsection{Deviations from the Plan as Approved}

This section is not applicable to CAU 548.

\subsection{CorRective Action SCHEdUle As COMPLETED}

Closure activities were conducted from July to December 2011. The start and end dates of field work for each CAS are provided in Table 2. Waste disposal took place after the end dates listed below in some cases.

TABle 2. Corrective Action Unit 548 Closure Activities Schedule

\begin{tabular}{|l|c|c|}
\hline \multicolumn{1}{|c|}{ CORRECTIVE ACTION SITE OR SITE DESCRIPTION } & START & END \\
\hline \hline 09-99-02, Material Piles (2) & $07 / 14 / 2011$ & $07 / 14 / 2011$ \\
\hline 09-99-04, Wax, Paraffin & $07 / 18 / 2011$ & $10 / 06 / 2011$ \\
\hline 09-99-05, Asbestos, Vermiculite & $07 / 18 / 2011$ & $07 / 18 / 2011$ \\
\hline 09-99-07, Tar Spill & $07 / 14 / 2011$ & $07 / 14 / 2011$ \\
\hline 10-22-38, Drum; Cable & $07 / 14 / 2011$ & $07 / 14 / 2011$ \\
\hline 12-99-08, Cement Spill & $07 / 12 / 2011$ & $07 / 12 / 2011$ \\
\hline 20-22-07, Drums (2) & $07 / 21 / 2011$ & $10 / 11 / 2011$ \\
\hline Area 9 Burn Pile & $07 / 14 / 2011$ & $07 / 14 / 2011$ \\
\hline Area 9 Stained Soil Areas & $10 / 06 / 2011$ & $12 / 06 / 2011$ \\
\hline Area 10 Lead Shot & $07 / 19 / 2011$ & $07 / 19 / 2011$ \\
\hline \hline
\end{tabular}

\subsection{Site Plan/Survey Plat}

This section is not applicable to CAU 548. 


\subsection{WASTE DISPOSITION}

This section describes the waste streams generated during closure activities and their final disposition.

\subsection{WASTE Minimization}

Industry standard waste minimization practices were applied throughout the course of closure activities. These practices included the following:

- Radiological surveys to verify acceptance of construction debris at the Area 9 U10c Sanitary Landfill

- Laboratory analysis to correctly characterize and segregate waste streams

- $\quad$ Size reduction of debris

\subsection{WAste MANAgement}

All waste was characterized and managed according to federal and state regulations, DOE orders, and NSTec procedures. Waste management areas (WMAs) were established throughout the project, as needed. All WMAs were identified with appropriate signs and boundaries to restrict unauthorized access. The WMAs were inspected on a weekly or monthly basis, as required, to ensure that all containers were intact, not leaking, and not exceeding storage duration times as specified by regulations and procedures. Applicable WMAs were posted as Radioactive Material Areas (RMAs) whenever radiological waste was stored in the area. Upon removal of radiologically impacted waste, the RMA was surveyed and de-posted.

Waste containers were purchased either new or reconditioned. All containers were inspected prior to use to verify that they were in good condition (e.g., no leaks, rust, or dents), lined or made of material that would not react with the waste, and met U.S. Department of Transportation requirements. The containers remained closed while stored unless waste was being added or removed. Containers were also handled in such a manner that the integrity of the container was not compromised. Appropriate labels were affixed, and relevant information was marked on the containers with an indelible marker. All information was legible and clearly visible.

\subsection{WASTE STREAMS AND DISPOSAL}

Waste disposition is summarized in Table 3 and discussed in detail in the following sections. Waste disposition documentation is included in Appendix B. 
TABLE 3. CoRrective Action UnIT 548 WASTE DisPosition SUMMARY

\begin{tabular}{|c|c|c|c|c|c|c|}
\hline $\begin{array}{l}\text { WASTE } \\
\text { STREAM }\end{array}$ & DESCRIPTION OF WASTE & VOLUME & $\begin{array}{c}\text { WASTE } \\
\text { CONTAINER }\end{array}$ & DATE OF DISPOSAL & $\begin{array}{c}\text { DISPOSITION } \\
\text { DOCUMENTATION }\end{array}$ & DISPOSITION \\
\hline \multirow{6}{*}{$\begin{array}{l}\text { Sanitary } \\
\text { Waste }\end{array}$} & CAS 09-99-02 Material Pile & $10 \mathrm{yd}^{3}$ & Unpackaged & $07 / 14 / 2011$ & \multirow{6}{*}{$\begin{array}{l}\text { Landfill Load } \\
\text { Verification Forms }\end{array}$} & \multirow{6}{*}{$\begin{array}{l}\text { Disposed at the Area } 9 \\
\text { U10c Sanitary Landfill }\end{array}$} \\
\hline & CAS 09-99-07 Tar Spill & $10 \mathrm{yd}^{3}$ & Unpackaged & 07/19/2011 & & \\
\hline & CAS 10-22-38 Debris & $10 \mathrm{yd}^{3}$ & Unpackaged & $07 / 14 / 2011$ & & \\
\hline & CAS 12-99-08 Cement and Asphalt Piles & $10 \mathrm{yd}^{3}$ & Unpackaged & 07/12/2011 & & \\
\hline & CAS 20-22-07 Empty Drums & $1 \mathrm{yd}^{3}$ & Unpackaged & $\begin{array}{l}07 / 26 / 2011 \\
10 / 11 / 2011\end{array}$ & & \\
\hline & CAS 20-22-07 Tires & $4 \mathrm{yd}^{3}$ & One B-25 box & $10 / 11 / 2011$ & & \\
\hline $\begin{array}{l}\text { Hydrocarbon } \\
\text { Waste }\end{array}$ & Area 9 Burn Pile & $20 \mathrm{yd}^{3}$ & Unpackaged & $\begin{array}{l}07 / 14 / 2011 \\
07 / 21 / 2011\end{array}$ & $\begin{array}{l}\text { Landfill Load } \\
\text { Verification Forms }\end{array}$ & $\begin{array}{l}\text { Disposed at the Area } 9 \\
\text { U10c Sanitary Landfill }\end{array}$ \\
\hline \multirow{3}{*}{ LLW } & CAS 09-99-05 Material Pile & $4 \mathrm{yd}^{3}$ & One B-25 box & 08/03/2011 & \multirow{3}{*}{$\begin{array}{l}\text { Certificates of } \\
\text { Disposal }\end{array}$} & \multirow{3}{*}{$\begin{array}{l}\text { Disposed at the Area } 5 \\
\text { RWMS }\end{array}$} \\
\hline & CAS 20-22-07 PPE & 55 gal & One 55-gal drum & $11 / 30 / 2011$ & & \\
\hline & Area 9 Stained Soil Areas & $36 \mathrm{yd}^{3}$ & Nine B-25 boxes & $\begin{array}{l}01 / 04 / 2012 \\
01 / 05 / 2012\end{array}$ & & \\
\hline HW & Area 10 Lead Shot & 275 gal & $\begin{array}{l}\text { Five 55-gal } \\
\text { drums }\end{array}$ & $01 / 17 / 2012$ & $\begin{array}{l}\text { Uniform HW } \\
\text { Manifest }\end{array}$ & $\begin{array}{l}\text { Disposed by U.S. Ecology } \\
\text { in Beatty, Nevada }\end{array}$ \\
\hline \multirow{2}{*}{ MW } & CAS 09-99-04 Material Pile and Soil & $36 \mathrm{yd}^{3}$ & Nine B-25 boxes & $06 / 27 / 2012$ & \multirow{2}{*}{$\begin{array}{l}\text { Certificates of } \\
\text { Disposal }\end{array}$} & \multirow{2}{*}{$\begin{array}{l}\text { Disposed at the Area } 5 \\
\text { RWMS }\end{array}$} \\
\hline & CAS 20-22-07 Lead Acid Battery & 55 gal & One 55-gal drum & 07/31/2012 & & \\
\hline
\end{tabular}

gal: gallon(s)

HW: hazardous waste

LLW: low-level waste

MW: mixed waste

PPE: personal protective equipment

RWMS: Radioactive Waste Management Site

$\mathrm{yd}^{3}$ : cubic yard(s) 


\subsubsection{Sanitary Waste}

Approximately $45 \mathrm{yd}^{3}$ of sanitary waste were generated during closure activities and transported to the Area 9 U10c Sanitary Landfill for disposal. Sanitary waste included approximately $10 \mathrm{yd}^{3}$ of material from the pile at CAS 09-99-02, approximately $10 \mathrm{yd}^{3}$ of material from the tar spill at CAS 09-99-07, approximately $10 \mathrm{yd}^{3}$ of debris from CAS 10-22-38, approximately $10 \mathrm{yd}^{3}$ of material from the piles at CAS 12-99-08, seven empty drums from CAS 20-22-07, and one B-25 box containing tires from CAS 20-22-07.

\subsubsection{Hydrocarbon Waste}

Approximately $20 \mathrm{yd}^{3}$ of hydrocarbon waste were generated during closure activities and transported to the Area 9 U10c Sanitary Landfill for disposal. Hydrocarbon waste included material from the Area 9 Burn Pile.

\subsubsection{Low-Level Waste}

Approximately $40 \mathrm{yd}^{3}$ of LLW were generated during closure activities and transported to the Area 5 RWMS for disposal. LLW included one B-25 box of material from the pile at CAS 09-99-05, one 55-gal drum of personal protective equipment from CAS 20-22-07, and nine B-25 boxes of material and soil from the Area 9 Stained Soil Areas.

\subsubsection{Hazardous Waste}

Approximately 275 gal of HW were generated during closure activities. In Area 10, lead and steel shot and associated soil was removed, packaged in five 55-gal drums, and transported to U.S. Ecology in Beatty, Nevada, for treatment and disposal as HW.

\subsubsection{Mixed Waste}

Approximately $36 \mathrm{yd}^{3}$ of MW were generated during closure activities. MW included nine B-25 boxes of material and soil from CAS 09-99-04 and one 55-gal drum containing a lead acid battery from CAS 20-22-07. The nine B-25 boxes of material and soil from CAS 09-99-04 were transported off site for treatment and returned to the NNSS for disposal at the Area 5 RWMS. The 55-gal drum containing a lead acid battery from CAS 20-22-07 was treated on site and disposed at the Area 5 RWMS. 
Revision: 0

Date: August 2012

THIS PAGE INTENTIONALLY LEFT BLANK 


\subsection{CLOSURE VERIFICATION RESULTS}

Site closure was verified by visual observations and by collecting and analyzing soil verification samples. Copies of the Sectored Housekeeping Site Closure Verification Forms are included as Appendix $\mathrm{C}$ of this report. These forms include before and after photographs of the sites, descriptions and removal status of waste, and waste disposal information.

Soil verification samples were collected after removal of waste at CAS 09-99-04, CAS 09-99-05, and the Area 9 First Stained Soil Area. Results verified that remaining soil does not contain contamination above action levels. Sample results for analytes detected above minimum detectable concentrations are summarized in the following tables, and the laboratory summary data reports are included in Appendix A.

Table 4. Verification Sample Results Detected Above Minimum Detectable CONCENTRATIONS FOR CORRECTIVE ACTION SITE 09-99-04

\begin{tabular}{||c|c|c||}
\hline \hline ANALYTE & ACTION LEVEL & SAMPLE RESULTS FOR 099904-V1 \\
\hline \hline Plutonium-238 & $13 \mathrm{pCi} / \mathrm{g}^{*}$ & $0.067 \mathrm{pCi} / \mathrm{g}$ \\
\hline Plutonium-239/240 & $12.7 \mathrm{pCi} / \mathrm{g}^{*}$ & $4.1 \mathrm{pCi} / \mathrm{g}$ \\
\hline Chromium & $450 \mathrm{mg} / \mathrm{kg}^{\dagger}$ & $5.99 \mathrm{mg} / \mathrm{kg}$ \\
\hline
\end{tabular}

mg/kg: milligram(s) per kilogram

pCi/g: picocurie(s) per gram

* Based on the construction, commercial, industrial land-use scenario in Table 2.1 of the National Council on Radiation Protection and Measurements (NCRP) Report No. 129, Recommended Screening Limits for Contaminated Surface Soil and Review Factors Relevant to Site-Specific Studies (NCRP, 1999). The values provided in this source document were scaled to a dose of 25 millirems per year.

† Based on U.S. Environmental Protection Agency Region 9 Regional Screening Levels for Industrial Soil

Table 5. Verification Sample Results Detected Above Minimum Detectable CONCENTRATIONS FOR CORRECTIVE ACTION SITE 09-99-05

\begin{tabular}{|c|c|c|}
\hline \hline ANALYTE & ACTION LEVEL & SAMPLE RESULTS FOR 548-099905 \\
\hline \hline Acetone & $23 \mathrm{mg} / \mathrm{kg}^{*}$ & $0.00698 \mathrm{mg} / \mathrm{kg}$ \\
\hline
\end{tabular}

mg/kg: milligram(s) per kilogram

* Based on U.S. Environmental Protection Agency Region 9 Regional Screening Levels for Industrial Soil

Table 6. Verification SAmple Results Detected Above Minimum Detectable Concentrations for the Area 9 First Stained SoIl Area

\begin{tabular}{|c|c|c||}
\hline ANALYTE & ACTION LEVEL & SAMPLE RESULTS FOR 548NSA-V1 \\
\hline \hline Chromium & $450 \mathrm{mg} / \mathrm{kg}^{*}$ & $20 \mathrm{mg} / \mathrm{kg}$ \\
\hline
\end{tabular}

mg/kg: milligram(s) per kilogram

* Based on U.S. Environmental Protection Agency Region 9 Regional Screening Levels for Industrial Soil 


\subsection{Data Quality Assessment}

Accurate and defensible analytical data were collected to verify that the closure objectives were met. Analytical data results are included as Appendix A. The following sections describe the quality assurance $(\mathrm{QA})$ and quality control $(\mathrm{QC})$ procedures and the data validation process. More detail on the QA/QC procedures can be found in the Industrial Sites Quality Assurance Project Plan (QAPP) (U.S. Department of Energy, National Nuclear Security Administration Nevada Operations Office [NNSA/NV], 2002).

\subsubsection{Quality Assurance and Quality Control Procedures}

Verification samples were collected with disposable sampling equipment, placed in appropriately labeled containers secured with custody seals, labeled with unique sample numbers, placed on ice, and transported under strict chain of custody. Standard QA/QC samples were collected (i.e., one blind duplicate per batch). Samples were analyzed by certified contract laboratories. Analytical results were validated at the laboratory using stringent QA/QC procedures, including matrix spike/matrix spike duplicates, spiked surrogate recovery analysis, verification of analytical results, and data quality indicator requirements.

\subsubsection{Data Validation}

Data validation was performed according to the QAPP (NNSA/NV, 2002), which is based on the U.S. Environmental Protection Agency (EPA) functional guidelines for data quality (EPA, 1994; 1999). Data were reviewed to ensure that samples were appropriately processed and analyzed and that the results are valid. All sample data were validated at the Tier I level.

No anomalies were discovered in the data that would discredit any of the sample results. Data met the required data quality indicators (i.e., precision, accuracy, sensitivity, completeness, comparability, and representativeness). The complete datasets, including validation reports, are maintained in the project files and available upon request.

\subsection{USE RESTRICTION}

Use restrictions were not implemented for any of the CASs in CAU 548, and the future land use of any land related to CAU 548 is not restricted from any activity. 


\subsection{CONCLUSIONS AND RECOMMENDATIONS}

\subsection{CONCLUSIONS}

Closure activities began in July 2011 and were completed in December 2011 and included removal and disposal of material piles, spills, sanitary debris, a lead acid battery, lead and steel shot, and stained soil.

\subsection{Post-Closure ReQuirements}

No use restrictions were implemented, and there are no post-closure requirements.

\subsection{RECOMMENDATIONS}

Because closure activities for CAU 548 have been completed as documented in this CR, NNSA/NSO requests the following:

- A Notice of Completion from the Nevada Division of Environmental Protection to NNSA/NSO for closure of CAU 548

- The transfer of CAU 548 from Appendix III to Appendix IV, Closed Corrective Action Units, of the FFACO 
CAU 548 Closure Report

Section: Conclusions and Recommendations

Revision: 0

Date: August 2012

THIS PAGE INTENTIONALLY LEFT BLANK 


\subsection{REFERENCES}

EPA, see U.S. Environmental Protection Agency.

Federal Facility Agreement and Consent Order, 1996 (as amended March 2010). Agreed to by the State of Nevada; U.S. Department of Energy, Environmental Management; U.S. Department of Defense; and U.S. Department of Energy, Legacy Management.

FFACO, see Federal Facility Agreement and Consent Order.

National Council on Radiation Protection and Measurements, 1999. Recommended Screening Limits for Contaminated Surface Soil and Review of Factors Relevant to Site-Specific Studies, Report No. 129. Bethesda, MD.

NNSA/NSO, see U.S. Department of Energy, National Nuclear Security Administration Nevada Site Office.

NNSA/NV, see U.S. Department of Energy, National Nuclear Security Administration Nevada Operations Office.

U.S. Department of Energy, National Nuclear Security Administration Nevada Operations Office, 2002. Nevada Environmental Restoration Project Industrial Sites Quality Assurance Project Plan, Nevada Test Site, Nevada. DOE/NV--372-REV.3. Las Vegas, NV.

U.S. Department of Energy, National Nuclear Security Administration Nevada Site Office, 2003. Sectored Clean-up Work Plan for Housekeeping Category Waste Sites. DOE/NV--579-REV-3. Las Vegas, NV.

U.S. Environmental Protection Agency, 1994. Guidance for the Data Quality Objectives Process. EPA QA/G-4. Washington, D.C.

U.S. Environmental Protection Agency, 1999. Contract Laboratory Program National Functional Guidelines for Organic Data Review. EPA540/R-99/008. Washington, D.C. 
CAU 548 Closure Report

Section: References

Revision: 0

Date: August 2012

THIS PAGE INTENTIONALLY LEFT BLANK 
CAU 548 Closure Report

Section: Appendix A

Revision: 0

Date: August 2012

\section{APPENDIX A}

\section{SAMPLE ANALYTICAL RESULTS}


CAU 548 Closure Report

Section: Appendix A

Revision: 0

Date: August 2012

\section{THIS PAGE INTENTIONALLY LEFT BLANK}




\section{Isotopic Plutonium By Alpha Spectroscopy Sample Results Summary}

Client Name: National Security Technologies, LLC

Client Project Name: CAU 548

Client Project Number: V366

Page: 1 of 1

Laboratory Name: ALS Environmental - FC

PAI Work Order: 1110209

Reported on: Monday, November 07, 2011

10:04:55 AM

\begin{tabular}{|c|c|c|c|c|c|c|c|c|c|c|}
\hline $\begin{array}{c}\text { Lab } \\
\text { Sample ID }\end{array}$ & Client Sample ID & $\begin{array}{l}\text { Sample } \\
\text { Type }\end{array}$ & Nuclide & Result $+1-2 \mathrm{~s}$ TPU & MDC & Units & Matrix & Prep Batch & $\begin{array}{c}\text { Date } \\
\text { Analyzed }\end{array}$ & Flags \\
\hline $1110209-1$ & $548 N S A-V 1$ & Sample & $P u-238$ & $7.41 \mathrm{E}-01+/-4.52 \mathrm{E}-01$ & 3.77E-01 & $\mathrm{pCi} / \mathbf{g}$ & SOIL & AS111025-1 & $10 / 29 / 2011$ & M3 \\
\hline $1110209-1$ & 548NSA-V1 & Sample & Pu-239/240 & $7.10 \mathrm{E}+01+1-1.26 \mathrm{E}+01$ & $5.65 \mathrm{E}-01$ & $\mathrm{pCi} / \mathrm{g}$ & SOIL & AS111025-1 & $10 / 29 / 2011$ & M3 \\
\hline $1110209-2$ & 099904-V1 & Sample & Pu-238 & $6.70 \mathrm{E}-02+/-2.01 \mathrm{E}-02$ & $2.93 \mathrm{E}-03$ & $\mathrm{pCi} / \mathrm{g}$ & SOIL & AS111018-1 & $10 / 21 / 2011$ & \\
\hline $1110209-2$ & 099904-V1 & Sample & Pu-239/240 & $4.10 \mathrm{E}+00+/-6.63 \mathrm{E}-01$ & $1.07 \mathrm{E}-02$ & $\mathrm{pCi} / \mathrm{g}$ & SOIL & AS111018-1 & $10 / 21 / 2011$ & \\
\hline $1110209-3$ & 548ANSA-C1 & Sample & Pu-238 & $4.47 \mathrm{E}-01+/-2.82 \mathrm{E}-01$ & $3.21 \mathrm{E}-01$ & $\mathrm{pCi} / \mathrm{g}$ & SOIL & AS111025-1 & $11 / 2 / 2011$ & M3 \\
\hline $1110209-3$ & 548ANSA-C 1 & Sample & Pu-239/240 & $3.88 \mathrm{E}+01+/-6.50 \mathrm{E}+00$ & $2.77 \mathrm{E}-01$ & $\mathrm{pCi} / \mathrm{g}$ & SOIL & AS111025-1 & $11 / 2 / 2011$ & M3 \\
\hline
\end{tabular}

Comments:

\section{ualifiersiFlags:}

$U$ - Result is less than the sample specific MDC.

LT - Result is less than Requested MDC, greater than sample specific MDC.

Abbreviations:

Y1 - Chemical Yield is in control at 100-110\%, Quantitative Yield is assumed.

TPU - Total Propagated Uncertainty

Y2 - Chemical Yield outside default limits.

$M$ - The requested MDC was not me

MDC - Minimum Detectable Concentration

M3 - The requested MDC was not met, but the reported activity is greater than the reported MDC.

$B D L$ - Below Detection Limit

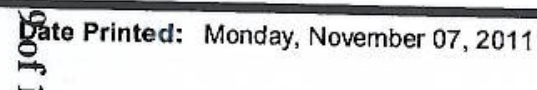

突 


\section{INORGANIC ANALYSIS DATA SHEET SW846 6010B}

Laboratory: Lionville Laboratory

Client: National Security Technologies, LLC

Matrix: $\underline{\text { Soil }}$

Laboratory ID: $1110059-01$

SDG: $\underline{\text { SDG \#V3667 }}$

Project: $\underline{\mathrm{CAU} 54 \underline{8}}$

Sampled: $\underline{10 / 12 / 1111: 50}$

Prepared: $10 / 19 / 1111: 31$

Solids: $\underline{97.37}$

Preparation: SW 3050B

File ID: ICP101911C-040

Batch: $\underline{\text { L110198 }}$

Sequence: $\quad \underline{1100100} \quad$ Calibration: UNASSIGNED Instrument: Thermo iTEVA

Sequence: $\quad \underline{1100100} \quad$ Calibration: UNASSIGNED Instrument: Thermo iTEVA

Analyzed: $10 / 20 / 1102: 33$

Initial/Final: $\underline{0.53 \mathrm{~g} / 50 \mathrm{~mL}}$

\begin{tabular}{|c|l|c|c|c|c|}
\hline CAS NO. & Analyte & $\begin{array}{c}\text { Concentration } \\
(\mathrm{mg} / \mathrm{kg} \text { dry })\end{array}$ & $\begin{array}{c}\text { Dilution } \\
\text { Factor }\end{array}$ & $\mathbf{Q}$ & Method \\
\hline $7440-47-3$ & Chromium & 5.99 & 1 & & SW846 6010B \\
\hline
\end{tabular}


Laboratory: Lionville Laboratory

Client: National Security Technologies, LLC

Matrix:

Sampled:

Solids:

Batch:
Soil

$\underline{10 / 12 / 1111: 50}$

$\underline{97.37}$
Laboratory ID:

Prepared:

Preparation:
SDG:

Project:

1110059-01

10/18/11 14:50

SW 3540C $\underline{\text { SDG \#V3667 }}$

CAU548

File ID:

D102111.D

Analyzed: $\quad \underline{10 / 21 / 1118: 08}$

Initial/Final: $\quad \underline{30.08 \mathrm{~g} / 1 \mathrm{~mL}}$

HP5972D

\begin{tabular}{|c|l|c|c|c|}
\hline CAS NO. & COMPOUND & DILUTION & CONC. (ug/kg dry) & Q \\
\hline $91-20-3$ & Naphthalene & 1 & 338 & U \\
\hline $91-57-6$ & 2-Methylnaphthalene & 1 & 338 & $\mathrm{U}$ \\
\hline $86-73-7$ & Fluorene & 1 & 338 & $\mathrm{U}$ \\
\hline $85-01-8$ & Phenanthrene & 1 & 338 & $\mathrm{U}$ \\
\hline $120-12-7$ & Anthracene & 1 & 338 & $\mathrm{U}$ \\
\hline $206-44-0$ & Fluoranthene & 1 & 338 & $\mathrm{U}$ \\
\hline $129-00-0$ & Pyrene & 1 & 338 & $\mathrm{U}$ \\
\hline $56-55-3$ & Benz[a]anthracene & 1 & 338 & $\mathrm{U}$ \\
\hline $218-01-9$ & Chrysene & 1 & 338 & $\mathrm{U}$ \\
\hline $205-99-2$ & Benzo[b] fluoranthene & 1 & 338 & $\mathrm{U}$ \\
\hline $207-08-9$ & Benzo[k] fluoranthene & 1 & 338 & $\mathrm{U}$ \\
\hline $50-32-8$ & Benzo[a] pyrene & 1 & 205 & $\mathrm{U}$ \\
\hline $191-24-2$ & Benzo[g,h,i]perylene & 338 & $\mathrm{U}$ \\
\hline
\end{tabular}

\begin{tabular}{|l|c|c|c|c|c|}
\hline SYSTEM MONITORING COMPOUND & ADDED (ug/kg dry) & CONC (ug/kg dry) & \% REC & QC LIMITS & Q \\
\hline 2-Fluorophenol & 2560.7 & 1230 & 48 & $25-121$ & \\
\hline Phenol-d5 & 2560.7 & 1810 & 71 & $24-113$ & \\
\hline Nitrobenzene-d5 & 1707.1 & 1200 & 70 & $23-120$ & \\
\hline 2-Fluorobiphenyl & 1707.1 & 1220 & 72 & $30-115$ & \\
\hline 2,4,6-Tribromophenol & 2560.7 & 1390 & 54 & $19-122$ & \\
\hline p-Terphenyl-d14 & 1707.1 & 1490 & 87 & $18-137$ & \\
\hline
\end{tabular}

\begin{tabular}{|l|c|c|c|c|c|}
\hline INTERNAL STANDARD & AREA & RT & REF AREA & REF RT & Q \\
\hline 1,4-Dichlorobenzene-d4 & 143791 & 8.343 & 169616 & 8.343 & \\
\hline Naphthalene-d8 & 537862 & 11.258 & 626724 & 11.266 & \\
\hline Acenaphthene-d10 & 259520 & 15.591 & 290357 & 15.599 & \\
\hline Phenanthrene-d10 & 403546 & 19.131 & 427977 & 19.14 & \\
\hline Chrysene-d12 & 358633 & 23.737 & 408204 & 23.745 & \\
\hline Perylene-d12 & 286634 & 28.052 & 305569 & 28.061 & \\
\hline
\end{tabular}

* Value outside of QC limits 
ORGANIC ANALYSIS DATA SHEET

8260B
Laboratory: Lionville Laboratory

Client: $\quad$ National Security Technologies, LLC

Matrix: $\quad$ Soil

Sampled: $\quad 10 / 12 / 1111: 50$

Solids:

97.37

$\underline{\mathrm{L} 110222}$
Laboratory ID:

Prepared:

Preparation:
SDG:

Project:

1110059-01

10/19/11 10:46

SW 5035A/5030A $\underline{\text { SDG \#V3667 }}$

CAU548

File ID:

E101906.D

Analyzed: $\quad 10 / 19 / 1110: 46$

Initial/Final: $\quad 4.97 \mathrm{~g} / 5 \mathrm{~mL}$
Instrument: 5972E

\begin{tabular}{|c|l|c|c|c|}
\hline CAS NO. & COMPOUND & DILUTION & CONC. (ug/kg dry) & Q \\
\hline $71-43-2$ & Benzene & 1 & 5.17 & U \\
\hline $100-41-4$ & Ethylbenzene & 1 & 5.17 & $\mathrm{U}$ \\
\hline $108-88-3$ & Toluene & 1 & 5.17 & $\mathrm{U}$ \\
\hline $1330-20-7$ & Xylenes, total & 1 & 5.17 & $\mathrm{U}$ \\
\hline $108-67-8$ & 1,3,5-Trimethylbenzene & 1 & 5.17 & $\mathrm{U}$ \\
\hline $103-65-1$ & n-Propylbenzene & 1 & 5.17 & $\mathrm{U}$ \\
\hline $104-51-8$ & n-Butylbenzene & 1 & 10.3 & $\mathrm{U}$ \\
\hline
\end{tabular}

\begin{tabular}{|c|c|c|c|c|c|}
\hline SYSTEM MONITORING COMPOUND & ADDED (ug/kg dry) & CONC (ug/kg dry) & $\%$ REC & QC LIMITS & Q \\
\hline 1,2-Dichloroethane-d4 & 51.660 & 56.3 & 109 & $60-130$ & \\
\hline Toluene- $\mathrm{d} 8$ & 51.660 & 55.8 & 108 & $72-117$ & \\
\hline 4-Bromofluorobenzene & 51.660 & 56.7 & 110 & $72-144$ & \\
\hline
\end{tabular}

* Value outside of QC limits 
Laboratory: Lionville Laboratory

Client: National Security Technologies, LLC

Matrix: $\quad \underline{\text { Soil }}$

Sampled: $\quad \underline{07 / 19 / 1111: 15}$

Solids: $\quad \underline{99.27}$

Batch:
SDG:

Project:

Laboratory ID:

Prepared:

Preparation: $\underline{1107121-02}$

$\underline{07 / 27 / 1114: 41}$

SW $3540 \mathrm{C}$ $\underline{\text { SDG \#3629 }}$

CAU548

File ID:

Analyzed: $\quad \underline{08 / 01 / 1116: 18}$

Initial/Final: $\quad \underline{30.52 \mathrm{~g} / 1 \mathrm{~mL}}$

\begin{tabular}{|c|c|c|c|c|}
\hline & $\underline{101295}$ & Calibration: & Instrument: & $\underline{\mathrm{HP} 5972 \mathrm{D}}$ \\
\hline CAS NO. & COMPOUND & DILUTION & CONC. (ug/kg dry) & $\mathrm{Q}$ \\
\hline $108-95-2$ & Phenol & 1 & 327 & $\mathrm{U}$ \\
\hline $111-44-4$ & Bis(2-chloroethyl) ether & 1 & 327 & $\mathrm{U}$ \\
\hline $95-57-8$ & 2-Chlorophenol & 1 & 327 & $\mathrm{U}$ \\
\hline $541-73-1$ & 1,3-Dichlorobenzene & 1 & 327 & $\mathrm{U}$ \\
\hline $106-46-7$ & 1,4-Dichlorobenzene & 1 & 327 & $\mathrm{U}$ \\
\hline $95-50-1$ & 1,2-Dichlorobenzene & 1 & 327 & $\mathrm{U}$ \\
\hline $95-48-7$ & 2-Methylphenol & 1 & 327 & $\mathrm{U}$ \\
\hline $108-60-1$ & Bis(2-chloroisopropyl) ether & 1 & 327 & $\mathrm{U}$ \\
\hline $65794-96-9$ & 3- and/or 4-Methylphenol & 1 & 327 & $\mathrm{U}$ \\
\hline $621-64-7$ & N-Nitrosodi-n-propylamine & 1 & 327 & $\mathrm{U}$ \\
\hline $67-72-1$ & Hexachloroethane & 1 & 327 & $\mathrm{U}$ \\
\hline $98-95-3$ & Nitrobenzene & 1 & 327 & $\mathrm{U}$ \\
\hline $78-59-1$ & Isophorone & 1 & 327 & $\mathrm{U}$ \\
\hline $88-75-5$ & 2-Nitrophenol & 1 & 327 & $\mathrm{U}$ \\
\hline $105-67-9$ & 2,4-Dimethylphenol & 1 & 327 & $\mathrm{U}$ \\
\hline $111-91-1$ & Bis(2-chloroethoxy) methane & 1 & 327 & U \\
\hline $120-83-2$ & 2,4-Dichlorophenol & 1 & 327 & $\mathrm{U}$ \\
\hline $120-82-1$ & 1,2,4-Trichlorobenzene & 1 & 327 & $\mathrm{U}$ \\
\hline $91-20-3$ & Naphthalene & 1 & 327 & $\mathrm{U}$ \\
\hline $106-47-8$ & 4-Chloroaniline & 1 & 327 & $\mathrm{U}$ \\
\hline $87-68-3$ & Hexachlorobutadiene & 1 & 327 & $\mathrm{U}$ \\
\hline $59-50-7$ & 4-Chloro-3-methylphenol & 1 & 327 & $\mathrm{U}$ \\
\hline $91-57-6$ & 2-Methylnaphthalene & 1 & 327 & $\mathrm{U}$ \\
\hline $77-47-4$ & Hexachlorocyclopentadiene & 1 & 327 & $\mathrm{U}$ \\
\hline $88-06-2$ & 2,4,6-Trichlorophenol & 1 & 327 & $\mathrm{U}$ \\
\hline $95-95-4$ & 2,4,5-Trichlorophenol & 1 & 327 & $\mathrm{U}$ \\
\hline $91-58-7$ & 2-Chloronaphthalene & 1 & 327 & $\mathrm{U}$ \\
\hline $88-74-4$ & 2-Nitroaniline & 1 & 1630 & $\mathrm{U}$ \\
\hline $131-11-3$ & Dimethyl Phthalate & 1 & 327 & $\mathrm{U}$ \\
\hline $606-20-2$ & 2,6-Dinitrotoluene & 1 & 327 & $\mathrm{U}$ \\
\hline $208-96-8$ & Acenaphthylene & 1 & 327 & $U$ \\
\hline $99-09-2$ & 3-Nitroaniline & 1 & 1630 & $\underline{U}$ \\
\hline $83-32-9$ & Acenaphthene & 1 & 327 & $\mathrm{U}$ \\
\hline $51-28-5$ & 2,4-Dinitrophenol & 1 & 1630 & $\mathrm{U}$ \\
\hline $100-02-7$ & 4-Nitrophenol & 1 & 1630 & $\mathrm{U}$ \\
\hline $132-64-9$ & Dibenzofuran & 1 & 327 & $\mathrm{U}$ \\
\hline $121-14-2$ & 2,4-Dinitrotoluene & 1 & 327 & $\mathrm{U}$ \\
\hline $84-66-2$ & Diethyl Phthalate & 1 & 327 & $\mathrm{U}$ \\
\hline $7005-72-3$ & 4-Chlorophenyl Phenyl Ether & 1 & 327 & $U$ \\
\hline $86-73-7$ & Fluorene & 1 & 327 & $\mathrm{U}$ \\
\hline
\end{tabular}




\section{ORGANIC ANALYSIS DATA SHEET \\ 8270C}

Laboratory: Lionville Laboratory

Client:

Matrix: Soil

Sampled:

Solids:

$\underline{07 / 19 / 1111: 15}$

$\underline{99.27}$
SDG:

Project:

Laboratory ID:

Prepared:

Preparation: $\underline{1107121-02}$

$\underline{07 / 27 / 11 \quad 14: 41}$

SW 3540C

Batch:

$\underline{\mathrm{L} 107295}$

Sequence: $\quad \underline{1080059}$

Calibration:

DILUTION

100-01-6

COMPOUND

$534-52-1$

4-Nitroaniline

86-30-6

4,6-Dinitro-2-methylphenol

101-55-3

$\mathrm{N}$-Nitrosodiphenylamine

$118-74-1$

4-Bromophenyl Phenyl Ether

$65-85-0$

87-86-5

100-51-6

85-01-8

120-12-7

84-74-2

206-44-0

129-00-0

85-68-7

117-81-7

91-94-1

$56-55-3$

218-01-9

117-84-0

205-99-2

207-08-9

50-32-8

193-39-5

53-70-3

191-24-2

126-73-8

Hexachlorobenzene

Benzoic Acid

Pentachlorophenol

Benzyl alcohol

Phenanthrene

Anthracene

Di-n-butyl Phthalate

Fluoranthene

Pyrene

Butyl Benzyl Phthalate

Bis(2-ethylhexyl) phthalate

3,3'-Dichlorobenzidine

Benz[a]anthracene

Chrysene

Di-n-octyl Phthalate

Benzo[b] fluoranthene

Benzo[k] fluoranthene

Benzo[a] pyrene

Indeno[1,2,3-cd]pyrene

Dibenz[a,h]anthracene

Benzo[g,h,i] perylene

\begin{tabular}{|l|l|}
\hline CAS NO. & TENTATIVELY IDENTIFIED COMPOUND \\
\hline NA & TIC:Aldol Condensate I \\
\hline NA & TIC:Aldol Condensate 2 \\
\hline NA & TIC:Aldol Condensate 3 \\
\hline NA & TIC:Aldol Condensate 4 \\
\hline NA & TIC:Aldol Condensate 5 \\
\hline NA & TIC:Alkane I \\
\hline NA & TIC:Trichloro-1-propene \\
\hline NA & TIC:Unknown 1 \\
\hline NA & TIC:Unknown 2 \\
\hline NA & TIC:Unknown 3 \\
\hline
\end{tabular}

1

1

1

$\frac{1}{1}$

1

1

1

1
1
1

1

1

$\frac{1}{1}$

1

1

1

1
1
1

1

$\frac{1}{1}$

1

\begin{tabular}{|c|c|}
\hline 1 & \\
\hline 1 & \\
\hline 1 & \\
\hline & $\mathrm{RT}$ \\
\hline & 3.62 \\
\hline 4.315 \\
\hline 4.544 \\
\hline 4.632 \\
\hline 6.339 \\
\hline 22.906 \\
\hline 4.878 \\
\hline 1.341 \\
\hline 2.019 \\
\hline 2.679 \\
\hline
\end{tabular}

1

2-Fluorophenol \begin{tabular}{|c|c|}
\hline ADDED (ug/kg dry) & C \\
\hline 2475.4 & \\
\hline
\end{tabular}

\begin{tabular}{c|} 
CONC (ug/kg dry) \\
\hline 1710 \\
\hline
\end{tabular}

$1 \%$

\section{$\underline{\text { SDG \#3629 }}$}

CAU548

File ID:

D080114.D

Analyzed: $\quad \underline{08 / 01 / 1116: 18}$

Initial/Final: $\quad 30.52 \mathrm{~g} / 1 \mathrm{~mL}$

1108018 Instrument: $\underline{\text { HP5972D }}$

\begin{tabular}{|c|c|}
\hline CONC. (ug/kg dry) & Q \\
\hline 1630 & U \\
\hline 327 & U \\
\hline 327 & U \\
\hline 327 & U \\
\hline 327 & U \\
\hline 1630 & U \\
\hline 1630 & U \\
\hline 327 & U \\
\hline 327 & U \\
\hline 327 & U \\
\hline 327 & U \\
\hline 327 & U \\
\hline 327 & U \\
\hline 327 & U \\
\hline 327 & U \\
\hline 654 & U \\
\hline 327 & U \\
\hline 327 & U \\
\hline 327 & U \\
\hline 327 & U \\
\hline 327 & U \\
\hline 327 & U \\
\hline 327 & U \\
\hline 327 & U \\
\hline 327 & U \\
\hline 327 & U \\
\hline
\end{tabular}


Laboratory: Lionville Laboratory

Client:

Matrix:

National Security Technologies, LLC

Sampled:

Soil

Solids:

$\underline{07 / 19 / 1111: 15}$

99.27

Batch:

$\underline{\mathrm{L} 107295}$

SYSTEM MONITORING COMPOUND

Phenol-d5

Nitrobenzene-d5

2-Fluorobiphenyl

2,4,6-Tribromophenol

p-Terphenyl-d14 Sequence: $\quad 1080059$
SDG:

Project:

Laboratory ID:

Prepared:

Preparation:

$1107121-02$

$\underline{07 / 27 / 1114: 41}$

SW 3540C

Calibration:

ADDED (ug/kg dry) CONC (ug/kg dry)

\begin{tabular}{|l|}
\hline INTERNAL STANDARD \\
\hline 1,4-Dichlorobenzene-d4 \\
\hline Naphthalene-d8 \\
\hline Acenaphthene-d10 \\
\hline Phenanthrene-d10 \\
\hline Chrysene-d12 \\
\hline Perylene-d12 \\
\hline
\end{tabular}

* Value outside of QC limits 
Laboratory: Lionville Laboratory

Client:

Matrix:

Sampled:

Solids:

National Security Technologies, LLC

Soil

Batch:

$\underline{07 / 19 / 1111: 15}$

99.27

L107261

Sequence:

Laboratory ID

Prepared:

Preparation:
SDG:

Project:

1107121-02

$\underline{07 / 25 / 11 \quad 10: 47}$

SW 5035A/5030A

Calibration: $\underline{\text { SDG \#3629 }}$

CAU548

File ID:

E072509.D

Analyzed: $\quad 07 / 25 / 1110: 47$

Initial/Final: $\quad \underline{5 \mathrm{~g} / 5 \mathrm{~mL}}$

Instrument: $\quad 5972 \mathrm{E}$

\begin{tabular}{|c|c|c|c|c|}
\hline & & Calibration: & Instrument: & 5972E \\
\hline CAS NO. & COMPOUND & DILUTION & CONC. (ug/kg dry) & $\mathrm{Q}$ \\
\hline $630-20-6$ & 1,1,1,2-Tetrachloroethane & 1 & 5.04 & $\mathrm{U}$ \\
\hline $71-55-6$ & 1,1,1-Trichloroethane & 1 & 5.04 & $\underline{U}$ \\
\hline $79-34-5$ & 1,1,2,2-Tetrachloroethane & 1 & 5.04 & $\mathrm{U}$ \\
\hline $79-00-5$ & 1,1,2-Trichloroethane & 1 & 5.04 & $\mathrm{U}$ \\
\hline $75-34-3$ & 1,1-Dichloroethane & 1 & 5.04 & $\mathrm{U}$ \\
\hline $75-35-4$ & 1,1-Dichloroethene & 1 & 5.04 & $\mathrm{U}$ \\
\hline $96-18-4$ & 1,2,3-Trichloropropane & 1 & 5.04 & $\mathrm{U}$ \\
\hline $120-82-1$ & 1,2,4-Trichlorobenzene & 1 & 5.04 & $\mathrm{U}$ \\
\hline $96-12-8$ & 1,2-Dibromo-3-chloropropane & 1 & 5.04 & $\mathrm{U}$ \\
\hline $106-93-4$ & 1,2-Dibromoethane & 1 & 5.04 & $\mathrm{U}$ \\
\hline $95-50-1$ & 1,2-Dichlorobenzene & 1 & 5.04 & $\mathrm{U}$ \\
\hline $107-06-2$ & 1,2-Dichloroethane & 1 & 5.04 & $\mathrm{U}$ \\
\hline $78-87-5$ & 1,2-Dichloropropane & 1 & 5.04 & $\mathrm{U}$ \\
\hline $541-73-1$ & 1,3-Dichlorobenzene & 1 & 5.04 & $\mathrm{U}$ \\
\hline $106-46-7$ & 1,4-Dichlorobenzene & 1 & 5.04 & $\mathrm{U}$ \\
\hline $78-93-3$ & 2-Butanone & 1 & 12.1 & $\mathrm{U}$ \\
\hline $591-78-6$ & 2-Hexanone & 1 & 12.1 & $\mathrm{U}$ \\
\hline $108-10-1$ & 4-Methyl-2-pentanone & 1 & 12.1 & $\mathrm{U}$ \\
\hline $67-64-1$ & Acetone & 1 & 6.98 & $\mathrm{~J}$ \\
\hline $71-43-2$ & Benzene & 1 & 5.04 & $\mathrm{U}$ \\
\hline $75-27-4$ & Bromodichloromethane & 1 & 5.04 & $\underline{U}$ \\
\hline $75-25-2$ & Bromoform & 1 & 5.04 & $\mathrm{U}$ \\
\hline $74-83-9$ & Bromomethane & 1 & 5.04 & $\mathrm{U}$ \\
\hline $75-15-0$ & Carbon Disulfide & 1 & 5.04 & $\mathrm{U}$ \\
\hline $56-23-5$ & Carbon Tetrachloride & 1 & 5.04 & $\mathrm{U}$ \\
\hline $108-90-7$ & Chlorobenzene & 1 & 5.04 & $\mathrm{U}$ \\
\hline $75-00-3$ & Chloroethane & 1 & 5.04 & $\mathrm{U}$ \\
\hline $67-66-3$ & Chloroform & 1 & 5.04 & $\mathrm{U}$ \\
\hline $74-87-3$ & Chloromethane & 1 & 5.04 & $\mathrm{U}$ \\
\hline $10061-01-5$ & cis-1,3-Dichloropropene & 1 & 5.04 & $\mathrm{U}$ \\
\hline $124-48-1$ & Dibromochloromethane & 1 & 5.04 & $\mathrm{U}$ \\
\hline $74-95-3$ & Dibromomethane & 1 & 5.04 & $\underline{\mathrm{U}}$ \\
\hline $75-71-8$ & Dichlorodifluoromethane & 1 & 5.04 & $\mathrm{U}$ \\
\hline $100-41-4$ & Ethylbenzene & 1 & 5.04 & $\mathrm{U}$ \\
\hline $87-68-3$ & Hexachlorobutadiene & 1 & 5.04 & $\mathrm{U}$ \\
\hline $75-09-2$ & Methylene Chloride & 1 & 13.5 & $\mathrm{~B}$ \\
\hline $91-20-3$ & Naphthalene & 1 & 5.04 & $\mathrm{U}$ \\
\hline $100-42-5$ & Styrene & 1 & 5.04 & $\mathrm{U}$ \\
\hline $127-18-4$ & Tetrachloroethene & 1 & 5.04 & $\mathrm{U}$ \\
\hline $108-88-3$ & Toluene & 1 & 5.04 & $\mathrm{U}$ \\
\hline
\end{tabular}


Laboratory: Lionville Laboratory

Client: National Security Technologies, LLC

Matrix: Soil

Sampled:

Solids:

$\underline{07 / 19 / 1111: 15}$

$\underline{99.27}$

L107261

Batch: Sequence:
Laboratory ID:

Prepared:

Preparation:
SDG:

Project:

$\underline{1107121-02}$

$\underline{07 / 25 / 11 \quad 10: 47}$

SW 5035A/5030A

Calibration:

$\underline{\text { SDG \#3629 }}$

CAU548

File ID:

Analyzed: $\quad \underline{07 / 25 / 1110: 47}$

Initial/Final: $\quad \underline{5 \mathrm{~g} / 5 \mathrm{~mL}}$

\begin{tabular}{|c|c|c|c|c|c|c|}
\hline & & & ration: & & Instrument: & $\underline{5972 \mathrm{E}}$ \\
\hline CAS NO. & COMPOUND & & DILUTION & $\mathrm{CON}$ & C. (ug/kg dry) & $\mathrm{Q}$ \\
\hline $156-60-5$ & trans-1,2-Dichloroethene & & 1 & & 5.04 & $\mathrm{U}$ \\
\hline $10061-02-6$ & trans-1,3-Dichloropropene & & 1 & & 5.04 & $\mathrm{U}$ \\
\hline $79-01-6$ & Trichloroethene & & 1 & & 5.04 & $\mathrm{U}$ \\
\hline $75-69-4$ & Trichlorofluoromethane & & 1 & & 5.04 & $\mathrm{U}$ \\
\hline $75-01-4$ & Vinyl chloride & & 1 & & 5.04 & $\mathrm{U}$ \\
\hline $1330-20-7$ & Xylenes, total & & 1 & & 5.04 & $\mathrm{U}$ \\
\hline $563-58-6$ & 1,1-Dichloropropene & & 1 & & 5.04 & $\mathrm{U}$ \\
\hline $87-61-6$ & 1,2,3-Trichlorobenzene & & 1 & & 5.04 & $\mathrm{U}$ \\
\hline $95-63-6$ & 1,2,4-Trimethylbenzene & & 1 & & 5.04 & $\mathrm{U}$ \\
\hline $108-67-8$ & 1,3,5-Trimethylbenzene & & 1 & & 5.04 & $\mathrm{U}$ \\
\hline $142-28-9$ & 1,3-Dichloropropane & & 1 & & 5.04 & $\mathrm{U}$ \\
\hline $590-20-7$ & 2,2-Dichloropropane & & 1 & & 5.04 & $\mathrm{U}$ \\
\hline $95-49-8$ & 2-Chlorotoluene & & 1 & & 5.04 & $\mathrm{U}$ \\
\hline $106-43-4$ & 4-Chlorotoluene & & 1 & & 5.04 & $\mathrm{U}$ \\
\hline $99-87-6$ & 4-Isopropyltoluene & & 1 & & 5.04 & $\mathrm{U}$ \\
\hline $108-86-1$ & Bromobenzene & & 1 & & 5.04 & $\mathrm{U}$ \\
\hline $74-97-5$ & Bromochloromethane & & 1 & & 5.04 & $U$ \\
\hline $156-59-2$ & cis-1,2-Dichloroethene & & 1 & & 5.04 & $\mathrm{U}$ \\
\hline 76-13-1 & Freon-113 & & 1 & & 5.04 & $\mathrm{U}$ \\
\hline $98-82-8$ & Isopropylbenzene & & 1 & & 5.04 & $U$ \\
\hline $104-51-8$ & n-Butylbenzene & & 1 & & 5.04 & $\mathrm{U}$ \\
\hline $103-65-1$ & n-Propylbenzene & & 1 & & 5.04 & $\mathrm{U}$ \\
\hline $135-98-8$ & sec-Butylbenzene & & 1 & & 5.04 & $\mathrm{U}$ \\
\hline $98-06-6$ & tert-Butylbenzene & & 1 & & 5.04 & $\mathrm{U}$ \\
\hline \multicolumn{2}{|c|}{ SYSTEM MONITORING COMPOUND } & ADDED (ug/kg dry) & CONC (ug/kg dry) & $\%$ REC & QC LIMITS & Q \\
\hline \multicolumn{2}{|c|}{ 1,2-Dichloroethane-d4 } & 50.367 & 51.0 & 101 & $60-130$ & \\
\hline \multirow{2}{*}{\multicolumn{2}{|c|}{$\begin{array}{l}\text { Toluene-d8 } \\
\text { 4-Bromofluorob }\end{array}$}} & 50.367 & 50.5 & 100 & $72-117$ & \\
\hline & & 50.367 & 50.5 & 100 & $72-144$ & \\
\hline
\end{tabular}

* Value outside of QC limits 


\section{Total ICP Metals}

\section{Method SW6010B \\ Sample Results}

Lab Name: ALS Environmental - FC

Work Order Number: 1112101

Client Name: National Security Technologies, LLC

ClientProject ID: CAU 548 V3669

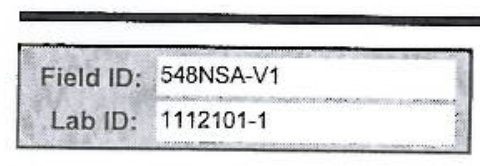

Sample Matrix: SOIL

$\%$ Moisture: 1.0

Date Collected: $12-$ Oct-11

Date Extracted: 12-Dec-11

Date Analyzed: 13-Dec-11

Prep Method: SW 3050 Rev B
Prep Batch: IP111212-4
QCBatchiD: IP111212-4-3
Run ID: IT111213-2A6
Cleanup: NONE
Sample Aliquot: $1.012 \mathrm{~g}$
Final Volume: $\quad 100 \mathrm{ml}$
Result Units: MG/KG
Clean DF: $\quad 1$

Basis: Dry Weight

File Name: $111213 \mathrm{~A}$.

\begin{tabular}{|l|l|r|r|r|r|r|c|}
\hline CASNO & Target Analyte & $\begin{array}{c}\text { Dilution } \\
\text { Factor }\end{array}$ & Result & $\begin{array}{c}\text { Reporting } \\
\text { Limit }\end{array}$ & IDL & $\begin{array}{c}\text { Result } \\
\text { Qualifier }\end{array}$ & $\begin{array}{c}\text { EPA } \\
\text { Qualifier }\end{array}$ \\
\hline $7440-47-3$ & CHROMUM & 1 & 20 & 1 & 0.051 & & \\
\hline
\end{tabular}


Revision: 0

Date: August 2012

\section{APPENDIX B}

WASTE DISPOSITION DOCUMENTATION 
CAU 548 Closure Report

Section: Appendix B

Revision: 0

Date: August 2012

\section{THIS PAGE INTENTIONALLY LEFT BLANK}


NSTec

Form

\begin{tabular}{llllll}
\hline SWO USE (Select One) & AREA & $\square 23$ & $\square 6$ & \ 9/10C & LANDFILL
\end{tabular}

For waste characterization, approval, and/or assistance, contact Solid Waste Operation (SWO) at 5-7898.

REQUIRED: WASTE GERERATOR INFORMATION

(This form is for rolloffs, dump trucks, and other onsite disposal of materials.)

Waste Generator: Jim Traynor

Phone Number: 5-4756

Location / Origin: CAU 548, Area 12 CAS 12-99-O8

Waste Category: (check one)

Waste Type: $\triangle$ NTS

$\square$ Commercial

Industrial

$\square$ Non-Putrescible

$\square$ Putrescrible

\ FFACO-onsite

(check one)

$\square$ Asbestos Containing Material

$\square$ FFACO-offsite

Pollution Prevention Category: (check one)

Environmental management

$\square$ Defense Projects

$\square$ WAC Exception

Pollution Prevention Category: (check one) $\triangle$ Clean-Up

Method of Characterization: (check one)

Sampling \& Analysis

$\square$ Routine

Prohibited Waste at all three Radioactive waste; RCRA waste; Hazardous waste; Free liquids, PCBs above TSCA regulatory NTS landfills:

Additional Prohibited Waste at the Area 9 U10C Landfill: levels, and Medical wastes (needles, sharps, bloody clothing).

Sewage Sludge, Animal carcasses, Wet garbage (food waste); and Friable asbestos

\section{REQUIRED: WASTE CONTENTS ALLOWABLE WASTES}

Check all allowable wastes that are contained within this load:

NOTE: Waste disposal at the Area 6 Hydrocarbon Landfill must have come into contact with petroleum hydrocarbons or coolants, such as: gasoline (no benzene, lead); jet fuel; diesel fuel; lubricants and hydraulics; kerosene; asphaltic petroleum hydrocarbon; and ethylene glycol.

\section{Acceptable waste at any NTS landfill: $\square$ Paper}

Asphalt $\quad$ Metal $\square$ Wood $\bigotimes$ Soil

$\bigotimes$ Soil

$\square$ Rocks / unaltered geologic materials

$\square$ Empty containers

$\triangle$ Plastic $\triangle$ Wire

Cable

$\square$ Rubber (excluding tires)

$\square$ Demolition debris

Manufactured items: (swamp coolers, furniture, rugs, carpet, electronic components, PPE, etc.)

Additional waste accepted at the Area 23 Mercury Landfill: $\square$ Office Waste

$\square$ Asbestos

Friable

Non-Friable (contact SWO if regulated load)

$\square$ Food Waste

Animal Carcasses

Additional waste accepted at the Area 9 U10c Landfill:

$\square$

Drained automobiles and military vehicles

Solid fractions from sand/oil/water

Light ballasts (contact SWO)

Drained fuel filters (gas \& diesel)

Deconned Underground and Above

Hydrocarbons (contact SWO)

Other

Ground Tanks

Additional waste accepted at the Area 6 Hydrocarbon Landfill:
$\square$ Septic sludge
$\square$ Rags
$\square$ Drained fuel filters (gas \& diesel)
Crushed non-teme plated oil filters
Plants
Soil
$\square$ Sludge from sand/oil/water separators
PCBs below 50 parts per million

Initials: REQUIRED: WASTE GENERATOR SIGNATURE

The above mentioned waste was generated outside of a Controlled Waste Management Area (CWMA) and to the best of my knowledge, does not contain radiological materials.

To the best of my knowledge, the waste described above contains only those materi site. I have verified this through the waste characterization method identified above prohibited and allowable waste items. I have contacted Property Management and $h$ is approved for disposal in the landfill.

Print Name:
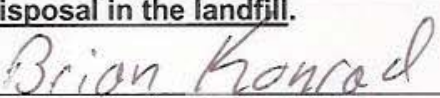

Signature: /s/: Brian Konrad Date:

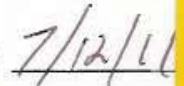

Radiological Survey Release for Waste Disposal RCT Initials

This container/load meets the criteria for no (1) added man-made radioactive material ( This container/load meets the criteria for Radcon Manual Table 4.2 release limits. $f$ This container/load is exempt from survey duoto process knowtedge and origin. SIGNATURE/S/: Signature on File

Note: "Food wasté, office trash and animal carcasses do not require a radiological clearance. Freon-contannıy appirances must have signed removal certification statement with Load Verification."

\section{SWO USE ONLY}

Load Weight (net from scale gestimate): 11,000 Signature of Certifier: /s/: Don Bickford 
Form

Rev. 01

FRM-0918

SWO USE (Select One) AREA

23

6

$\triangle 9 / 10 C$

LANDFILL

For waste characterization, approval, and/or assistance, contact Solid Waste Operation (SWO) at 5-7898.

REQUIRED: WASTE GERERATOR INFORMATION

(This form is for rolloffs, dump trucks, and other onsite disposal of materials.)

Waste Generator: James Traynor

Phone Number: $5-4756$

Location / Origin: CAU 548 Area 9, CAS 09-99-02, Burn Pile

Waste Category: (check one)

Waste Type: $\square$ NTS

$\square$ Commercial

$\triangle$ Industrial

(check one)

$\square$ Asbestos Containing Material

$\triangle$ FFACO-onsite

Pollution Prevention Category: (check one) $\bigotimes$ Environmental management

Pollution Prevention Category: (check one) $\triangle$ Clean-Up

$\square$ FFACO-offsite

Method of Characterization: (check one)

$\triangle$ Sampling \& Analysis

$\square$ Defense Projects

$\square$ Historic DOE/NV

Prohibited Waste at all three

NTS landfills:

Additional Prohibited Waste

at the Area 9 U10C Landfill:

levels, and Medical wastes (needles, sharps, bloody clothing).

Sewage Sludge, Animal carcasses, Wet garbage (food waste); and Friable asbestos

\section{REQUIRED: WASTE CONTENTS ALLOWABLE WASTES}

Check all allowable wastes that are contained within this load:

NOTE: Waste disposal at the Area 6 Hydrocarbon Landfill must have come into contact with petroleum hydrocarbons or coolants, such as: gasoline (no benzene, lead); jet fuel; diesel fuel; lubricants and hydraulics; kerosene; asphaltic petroleum hydrocarbon; and ethylene glycol.
Acceptable waste at any NTS landfill:
Q Paper
$\square$ Rocks / unaltered geologic materials
Empty containers
$\bigotimes$ Asphalt $\square$ Metal
$\triangle$ Wood
$\triangle$ Soil
$\square$ Rubber (excluding tires)
Cloth
$\square$ Insulation (non-Asbestosform)
$\triangle$ Demolition debris
$\square$ Plastic $\bigotimes$ Wire
$\square$ Cable
urniture, rugs,
carpet, electronic components, PPE, etc.)
$\triangle$ Cement \& concrete

Additional waste accepted at the Area 23 Mercury Landfill: $\square$ Office Waste

$\square$ Asbestos

$\square$ Friable

Non-Friable (contact SWO if regulated load)

$\square$ Food Waste

Animal Carcasses

Additional waste accepted at the Area 9 U10c Landfill:
$\square$ Non-friable asbestos
$\square$ Drained automobiles and military vehicles

\section{$\square$ Light ballasts (contact SWO)}
$\triangle$ Hydrocarbons (contact SWO
Drained fuel filters (gas \& diesel)
Other

Quantity:

Solid fractions from sand/oil/water

Deconned Underground and Above

Ground Tanks

Additional waste accepted at the Area 6 Hydrocarbon Landfill:

$\begin{array}{ll}\square \text { Septic sludge } & \square \text { Rags } \\ \square \text { Plants } & \square \text { Soil }\end{array}$

$\square$ Drained fuel filters (gas \& diesel)

Crushed non-teme plated oil filters

$\square$ Sludge from sand/oil/water separators

REQUIRED: WASTE GENERATOR SIGNATURE

PCBs below 50 parts per million

Initials:

(if initialed, no radiological clearance is necessary.)

The above mentioned waste was generated outside of a Controlled Waste Management Area (CWMA) and to the best of my

knowledge, does not contain radiological materials.

To the best of my knowledge, the waste described above contains only those mate site. I have verified this through the waste characterization method identified abov prohibited and allowable waste items. I have contacted Property Management and is approved for disposal in the landfill.

Print Name: Brian Konrad

Signature: /s/: Brian Konrad

Date: $7 / 14 / 11$

Note: "Food waste, office trash and animal carcasses do not require a radiological must have signed removal certification statement with Load Verification."

\section{SWO USE ONLY}

Load Weight (net from scale or estimate): $21,6 \mathrm{elO}$ Signature of Certifier: /s/: Don Bickford Radiological Survey Release for Waste Disposa
RCT Initials

This container/load meets the criteria for no added man-made radioactive material

This container/load meets the criteria for

Radcon Manual Table 4.2 release limits.

This container/load is exempt from survey .

SIGNATURE /s/: Signature on File 
For waste characterization, approval, and/or assistance, contact Solid Waste Operation (SWO) at 5-7898.

\section{REQUIRED: WASTE GERERATOR INFORMATION}

(This form is for rolloffs, dump trucks, and other onsite disposal of materials.)

Waste Generator: Jim Traynor

Phone Number: 5-4756

Location / Origin: $\quad$ CAU 548, Area 10

CAS $10-22-38$

Waste Category: (check one)

Waste Type: $\square$ NTS

$\square$ Commercial

$\bigotimes$ Industrial

(check one)

$\square$ Non-Putrescible

$\square$ Putrescrible

E FFACO-onsite

$\square$ WAC Exception

Pollution Prevention Category: (check one)

$\square$ Asbestos Containing Material

$\square$ FFACO-offsite

$\bigotimes$ Environmental management

Pollution Prevention Category: (check one) $\bigotimes$ Clean-Up

Method of Characterization: (check one)

Sampling \& Analysis

$\square$ Defense Projects

$\square$ Historic DOE/NV

Prohibited Waste at all three

NTS landfills:

Additional Prohibited Waste

at the Area 9 U10C Landfill:

\section{levels, and Medical wastes (needles, sharps, bloody clothing).}

Sewage Sludge, Animal carcasses, Wet garbage (food waste); and Friable asbestos

\section{REQUIRED: WASTE CONTENTS ALLOWABLE WASTES}

Check all allowable wastes that are contained within this load:

NOTE: Waste disposal at the Area 6 Hydrocarbon Landfill must have come into contact with petroleum hydrocarbons or coolants, such as: gasoline (no benzene, lead); jet fuel; diesel fuel; lubricants and hydraulics; kerosene; asphaltic petroleum hydrocarbon; and ethylene glycol.
Acceptable waste at any NTS landfill:
$\square$ Paper
$\square$ Rocks / unaltered geologic materials
$\bigotimes$ Empty containers
$\square$ Asphalt
$\bigotimes$ Metal
$\bigotimes$ Wood
\ Soil
$\square$ Rubber (excluding tires)
$\square$ Demolition debris
$\bigotimes$ Plastic $\bigotimes$ Wire
$\bigotimes$ Cable
$\square$ Cloth
$\square$ Insulation (non-Asbestosform)
$\bigotimes$ Cement \& concrete
Manufactured items: (swamp coolers, furniture, rugs, carpet, electronic components, PPE, etc.)
Additional was
23 Mercury Landfill:
Office Waste
Food Waste
Animal Carcasses

Additional waste accepted at the Area 9 U10c Landfill:

$\square$ Non-friable asbestos

$\square$ Light ballasts (contact SWO)

$\square$ Hydrocarbons (contact SWO
$\square$ Drained automobiles and military vehicles
Drained fuel filters (gas \& diesel)

Other
Solid fractions from sand/oil/water

$\square$ Deconned Underground and Above Ground Tanks

Additional waste accepted at the Area 6 Hydrocarbon Landfill:
$\square$ Septic sludge
$\square$ Rags
$\square$ Drained fuel filters (gas \& diesel)
Crushed non-teme plated oil filters
Plants
$\square$ Soil
$\square$ Sludge from sand/oil/water separators
$\square$ PCBs below 50 parts per million REQUIRED: WASTE GENERATOR SIGNATURE

Initials: (if initialed, no radiological clearance is necessary.)

The above mentioned waste was generated outside of a Controlled Waste Management Area (CWMA) and to the best of my knowledge, does not contain radiological materials.

To the best of my knowledge, the waste described above contains only those mate site. I have verified this through the waste characterization method identified abov prohibited and allowable waste items. I have contacted Property Management and is approved for disposal in the landfill.

Print Name:

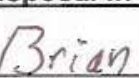

Q

Signature: /s/: Brian Konrad Date:

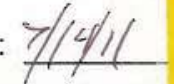

Note: "Food waste, office trash and animal carcasses do not require a radiological c must have signed removal certification statement with Load Verification."

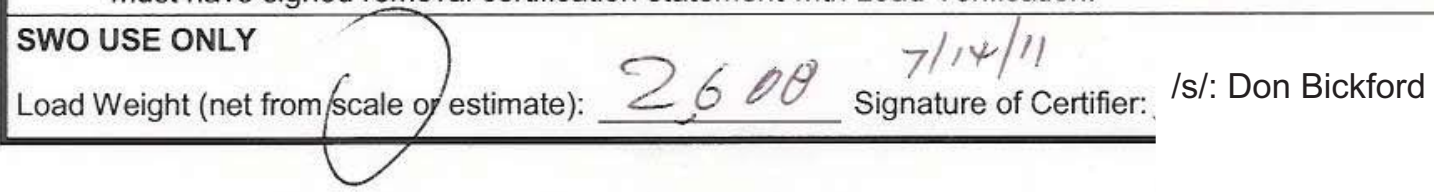

Radiological Survey Release for Waste Disposal RCT Initials

This container/load meets the criteria for no added man-made radioactive material

$X$ This container/load meets the criteria for Radcon Manual Table 4.2 release limits. This container/load is exempt from survey due to process knowledge and origin. SIGNATURE:/S/: Signature on FiledATE:

\section{SWO USE ONLY}

Load Weight (net from/scale op estimate):

$$
7 / \% / 11
$$

Signature of Certifier: 
Form

For waste characterization, approval, and/or assistance, contact Solid Waste Operation (SWO) at 5-7898.

REQUIRED: WASTE GERERATOR INFORMATION

(This form is for rolloffs, dump trucks, and other onsite disposal of materials.)

Waste Generator: James Traynor

Phone Number: 5-4756

Location / Origin: CAU 548 Area 9, CAS 09-99-07

Waste Category: (check one)

Waste Type: $\bigotimes$ NTS

(check one)

$\square$ Non-Putrescible

$\square$. Commercial
$\square$ Putrescrible
$\square$ Asbestos Containing Material

$\bigotimes$ Industrial

Pollution Prevention Category: (check one) $\bigotimes$ Environmental management

Pollution Prevention Category: (check one) $\bigotimes$ Clean-Up

$\triangle$ FFACO-onsite

Method of Characterization: (check one)

$\triangle$ Sampling \& Analysis

$\square$ FFACO-offsite

$\square$ WAC Exception

Prohibited Waste at all three Radioactive waste; RCRA waste; Hazardous waste; Free liquids, PCBs above TSCA regulatory

NTS landfills:

levels, and Medical wastes (needles, sharps, bloody clothing).

Additional Prohibited Waste

at the Area 9 U10C Landfill:

Sewage Sludge, Animal carcasses, Wet garbage (food waste); and Friable asbestos

\section{REQUIRED: WASTE CONTENTS ALLOWABLE WASTES}

Check all allowable wastes that are contained within this loa\%:

NOTE: Waste disposal at the Area 6 Hydrocarbon Landfill must have come into contact with petroleum hydrocarbons or coolants, such as: gasoline (no benzene, lead); jet fuel; diesel fuel; lubricants and hydraulics; kerosene; asphaltic petroleum hydrocarbon; and ethylene glycol.
Acceptable waste at any NTS landfill:
\ Paper
$\square$ Rocks / unaltered geologic materials
$\square$ Rubber (excluding tires)
$\triangle$ Soil
$\square$ Insulation (non-Asbestosform)
$\square$ Empty containers
$\bigotimes$ Demolition debris
凶 Asphalt
$\square$ Metal
$\triangle$ Wood
$\triangle$ Cloth
$\otimes$ Cement \& concrete

$\square$ Manufactured items: (swamp coolers, furniture, rugs, carpet, electronic components, PPE, etc.)
Additional waste accepted at the Area 23 Mercury Landfill:
$\square$ Office Waste
$\square$ Food Waste
Animal Carcasses
$\square$ Asbestos
Friable
Non-Friable (contact SWO if regulated load)
Quantity:

Additional waste accepted at the Area 9 U10c Landfill:
$\square$ Non-friable asbestos
$\square$ Drained automobiles and military vehicles
Solid fractions from sand/oil/water
$\square$ Light ballasts (contact SWO)
$\square$ Drained fuel filters (gas \& diesel)
Deconned Underground and Above
$\triangle$ Hydrocarbons (contact SWO Other Ground Tanks

Additional waste accepted at the Area 6 Hydrocarbon Landfill:
$\square$ Septic sludge
$\square$ Rags
$\square$. Drained fuel filters (gas \& diesel)
G. Sludge from sand/oil/water separators

\section{Crushed non-teme plated oil filters PCBs below 50 parts per million} REQUIRED: WASTE GENERA

Initials: (if initialed, no radiological clearance is necessary.)

The above mentioned waste was generated outside of a Controlled $W_{c}$ knowledge, does not contain radiological materials.

To the best of my knowledge, the waste described above contains onl site. I have verified this through the waste characterization method id prohibited and allowable waste items. I have contacted Property Man: is approved for disposal in the landfill.

Print Name: Brian Konrad

Signature: /s/: Brian Konrad

Date: $7 / 14 / 11$

Radiological Survey Release for Waste Disposal RCT Initials

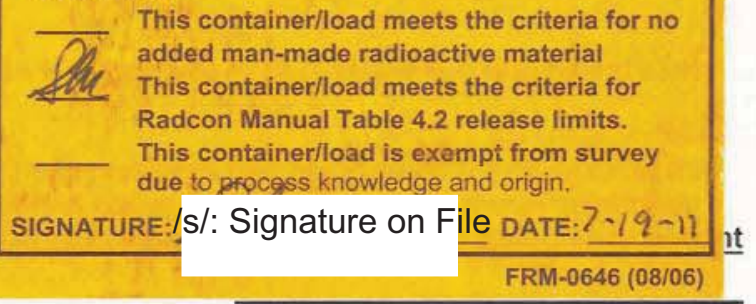

Note: "Food waste, office trash and animal carcasses do not require a radiological clearance. Freon-containing appliances must have signed removal certification statement with Load Verification."

SWO USE ONLY

Load Weight (net from scale or estimate):

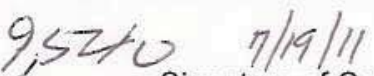
Signature of Certifier: /s/: Don Bickford here. Onsite use only. 


\begin{tabular}{|lrr|}
\hline $\begin{array}{l}\text { NSTec } \\
\text { Form } \\
\text { FRM-0918 }\end{array}$ & 2 & $\begin{array}{r}10 / 07 / 09 \\
\text { Rev. 01 } \\
\text { Page 1 of 2 }\end{array}$ \\
\hline
\end{tabular}

\begin{tabular}{|llllll}
\hline SWO USE (Select One) & AREA & $\square 23$ & $\square 6$ & Q $9 / 10 \mathrm{C}$ & LANDFILL
\end{tabular}

For waste characterization, approval, and/or assistance, contact Solid Waste Operation (SWO) at 5-7898.

REQUIRED: WASTE GERERATOR INFORMATION

(This form is for rolloffs, dump trucks, and other onsite disposal of materials.)

Waste Generator: James Traynor

Phone Number: $5-4756$

Location / Origin: CAU 548 Area 9, CAS 09-99-02, Burn Pile

\begin{tabular}{|c|c|c|c|c|}
\hline \multicolumn{2}{|c|}{ Waste Category: (check one) } & \multirow{2}{*}{$\begin{array}{l}\square \text { Commercial } \\
\square \text { Putrescrible }\end{array}$} & \multicolumn{2}{|l|}{$\otimes$ Industrial } \\
\hline Waste Type: & $\triangle \mathrm{NTS}$ & & $\triangle$ FFACO-onsite & $\square$ WAC Exception \\
\hline (check one) & $\square$ Non-Putrescible & $\square$ Asbestos Containing Material & $\square$ FFACO-offsite & $\square$ Historic DOE/NV \\
\hline \multicolumn{2}{|c|}{ Pollution Prevention Category: (check one) } & $\triangle$ Environmental management & $\square$ Defense Projects & $\square \mathrm{YMP}$ \\
\hline \multicolumn{2}{|c|}{ Pollution Prevention Category: (check one) } & $\triangle$ Clean-Up & $\square$ Routine & \\
\hline \multicolumn{2}{|c|}{ Method of Characterization: (check one) } & $\bigotimes$ Sampling \& Analysis & $\square$ Process Knowledge & $\square$ Contents \\
\hline
\end{tabular}

Prohibited Waste at all three Radioactive waste; RCRA waste; Hazardous waste; Free liquids, PCBs above TSCA regulatory NTS landfills:

levels, and Medical wastes (needles, sharps, bloody clothing).

Additional Prohibited Waste

at the Area 9 U10C Landfill:

Sewage Sludge, Animal carcasses, Wet garbage (food waste); and Friable asbestos

\section{REQUIRED: WASTE CONTENTS ALLOWABLE WASTES}

Check all allowable wastes that are contained within this load:

NOTE: Waste disposal at the Area 6 Hydrocarbon Landfill must have come into contact with petroleum hydrocarbons or coolants, such as: gasoline (no benzene, lead); jet fuel; diesel fuel; lubricants and hydraulics; kerosene; asphaltic petroleum hydrocarbon; and ethylene glycol.
Acceptable waste at any NTS landfill:
$\triangle$ Paper
$\bigotimes$ Soil
$\square$ Rocks / unaltered geologic materials
$\square$ Rubber (excluding tires)
$\otimes$ Cloth
$\square$ Insulation (non-Asbestosform)
$\square$ Empty containers
$\square$ Demolition debris
$\square$ Cement \& concrete
$\square$ Plastic
$\triangle$ Wire
$\square$ Cable
Manufactured items: (swamp coolers, furniture, rugs, carpet, electronic components, PPE, etc.)
Additional waste accepted at the Area 23 Mercury Landfill: $\square$ Office Waste $\square$ Food Waste $\square$ Animal Carcasses
$\square$ Asbestos $\quad \square$ Friable $\quad \square$ Non-Friable (contact SWO if regulated load) Quantity:

Additional waste accepted at the Area 9 U10c Landfill:

$\begin{array}{ll}\square \text { Non-friable asbestos } & \square \text { Drained automobiles and military vehicles } \\ \square \text { Light ballasts (contact SWO) } & \square \text { Drained fuel filters (gas \& diesel) } \\ \bigotimes \text { Hydrocarbons (contact SWO) } & \square \text { Other }\end{array}$

Solid fractions from sand/oil/water

$\square$ Deconned Underground and Above

Ground Tanks

\begin{tabular}{|c|c|c|c|}
\hline \multicolumn{4}{|c|}{ Additional waste accepted at the Area 6 Hydrocarbon Landfill: $\square$} \\
\hline$\square$ Septic sludge & $\square$ Rags & $\square$ Drained fuel filters (gas \& diesel) & $\square$ Crushed non-teme plated oil filters \\
\hline$\square$ Plants & $\square$ Soil & $\square$ Sludge from sand/oil/water separators & $\square$ PCBs below 50 parts per million \\
\hline
\end{tabular}

Initials:

(if initialed, no radiological clearance is necessary.)

The above mentioned waste was generated outside of a Controlled Waste Management Area (CWMA) and to the best of my knowledge, does not contain radiological materials.

To the best of my knowledge, the waste described above contains only those materials that are allowed for disnneal at thin site. I have verified this through the waste characterization method identified a' prohibited and allowable waste items. I have contacted Property Management is approved for disposal in the landfill.

Print Name: Brian Konrad

Signature: /s/: Brian Konrad Date: $7 / 14 / 1$

Note: "Food waste, office trash and animal carcasses do not require a radiologic: must have signed removal certification statement with Load Verification."

SWO USE ONLY

Load Weight (net fron scale)or estimate): 10320 $7 / 21 / 11$ Signature of Certifier: _/s/: Signature on File

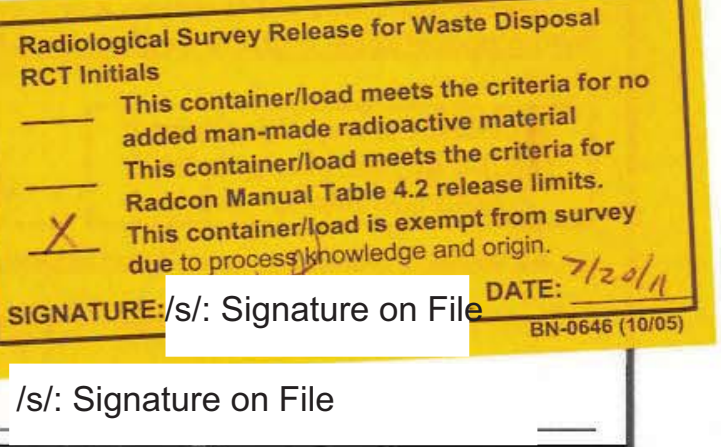




\begin{tabular}{llllll}
\hline SWO USE (Select One) & AREA & $\square 23$ & $\square 6$ & \ 9 & \ LANDFILL
\end{tabular}

For waste characterization, approval, and/or assistance, contact Solid Waste Operation (SWO) at 5-7898.

REQUIRED: WASTE GERERATOR INFORMATION

(This form is for rolloffs, dump trucks, and other onsite disposal of materials.)

Waste Generator: MIKE FLOYD

Phone Number: 295-6653

Location / Origin: $\quad$ CAU 548 --CAS 20-22-07 --area 20

Waste Category: (check one)

Waste Type: $\square$ NTS

$\square$ Commercial

$\triangle$ Industrial

(check one)

$\square$ Non-Putrescible

$\square$ Putrescrible

$\triangle$ FFACO-onsite

WAC Exception

Pollution Prevention Category: (check one)

$\square$ Asbestos Containing Material

$\square$ FFACO-offsite

$\square$ Historic DOE/NV

Pollution Prevention Category: (check one)

Environmental management

$\square$ Defense Projects YMP

Method of Characterization: (check one)

Clean-Up

$\square$ Routine

Prohibited Waste at all three

NTS landfills:

$\triangle$ Process Knowledge $\square$ Contents

Additional Prohibited Waste

at the Area 9 U10C Landfill:

Radioactive waste; RCRA waste; Hazardous waste; Free liquids, PCBs above TSCA regulatory levels, and Medical wastes (needles, sharps, bloody clothing).

Sewage Sludge, Animal carcasses, Wet garbage (food waste); and Friable asbestos

REQUIRED: WASTE CONTENTS ALLOWABLE WASTES

Check all allowable wastes that are contained within this load:

NOTE: Waste disposal at the Area 6 Hydrocarbon Landfill must have come into contact with petroleum hydrocarbons or coolants, such as: gasoline (no benzene, lead); jet fuel; diesel fuel; lubricants and hydraulics; kerosene; asphaltic petroleum hydrocarbon; and ethylene glycol.
Acceptable waste at any NTS landfill:
$\square$ Paper
$\square$ Rocks / unaltered geologic materials
Empty containers
$\square$ Asphalt $\bigotimes$ Metal
$\square$ Wood
$\square$ Soil
$\square$ Rubber (excluding tires)
$\square$ Plastic $\square$ Wire
Cable
$\square$ Insulation (non-Asbestosform)
Demolition debris
$\square$ Cloth
Cement \& concrete

Manufactured items: (swamp coolers, furniture, rugs, carpet, electronic components, PPE, etc.)

Additional waste accepted at the Area 23 Mercury Landfill: $\square$ Office Waste $\square$ Food Waste $\square$ Animal Carcasses $\square$ Asbestos $\quad \square$ Friable $\quad \square$ Non-Friable (contact SWO if regulated load) Quantity:

Additional waste accepted at the Area 9 U10c Landfill:
$\bigotimes$ Non-friable asbestos
Drained automobiles and military vehicles
Solid fractions from sand/oil/water
Light ballasts (contact SWO)
Drained fuel filters (gas \& diesel)
Deconned Underground and Above
Hydrocarbons (contact SWO)
Other
Ground Tanks

Additional waste accepted at the Area 6 Hydrocarbon Landfill:
$\square$ Septic sludge
$\square$ Rags
$\square$ Drained fuel filters (gas \& diesel)
Crushed non-teme plated oil filters
Plants
Soil
$\square$ Sludge from sand/oil/water separators PCBs below 50 parts per million
REQUIRED: WASTE GENERATOR SIGNATURE

Initials: (if initialed, no radiological clearance is necessary.)

The above mentioned waste was generated outside of a Controlled Waste Management Area (CWMA) and to the best of my knowledge, does not contain radiological materials.

To the best of my knowledge, the waste described above contains only those materials that are allowed for disposal at this site. I have verified this through the waste characterization method identified abovi prohibited and allowable waste items. I have contacted Property Management and is approved for disposal in the landfill.

Print Name: MIKE FLOYD

Signature: /s/: Mike Floyd

Radiological Survey Release for Waste Disposal RCT Initials

This container/load meets the criteria for no $\checkmark$ added man-made radioactive material

A This container/ioad meets the criteria for Radcon Manual Table 4.2 release limits. This container/load is exempt from survey due to process knewledge and origin.

Note: "Food waste, office trash and animal carcasses do not require a radiological c must have signed removal certification statement with Load Verification."

\section{SWO USE ONLY}

Load Weight (net from scale or estimate): 100

$$
7 / 26 / 11
$$

Signature of Certifier: _s/: Signature on File 
$\begin{array}{llllll}\text { SWO USE (Select One) } & \text { AREA } & \square 23 & \square 6 & \text { X } 9 & \text { \ LANDFILL }\end{array}$

For waste characterization, approval, and/or assistance, contact Solid Waste Operation (SWO) at 5-7898.

REQUIRED: WASTE GERERATOR INFORMATION

(This form is for rolloffs, dump trucks, and other onsite disposal of materials.)

Waste Generator: MIKE FLOYD Phone Number: 295-6653

Location / Origin: $\quad$ CAU 548 --CAS 20-22-07 --area 20

$$
F A x-5-7761 / 7918
$$

Waste Category: (check one)

Waste Type: \ NTS

$\square$ Commercial

\ Industrial

(check one)

Non-Putrescible

$\square$ Putrescrible

$\triangle$ FFACO-onsite

$\square$ WAC Exception

Pollution Prevention Category: (check one)

Pollution Prevention Category: (check one)

$\square$ Asbestos Containing Material

$\square$ FFACO-offsite

$\square$ Historic DOE/NV

$\triangle$ Clean-Up

Method of Characterization: (check one) \ Sampling \& Analysis

$\square$ Defense Projects

YMP

Prohibited Waste at all three Radioactive waste; RCRA waste; Hazardous waste; Free liquids, PCBs above TSCA regulatory NTS landfills:

Additional Prohibited Waste at the Area 9 U10C Landfill: levels, and Medical wastes (needles, sharps, bloody clothing).

Sewage Sludge, Animal carcasses, Wet garbage (food waste); and Friable asbestos

REQUIRED: WASTE CONTENTS ALLOWABLE WASTES

Check all allowable wastes that are contained within this load:

NOTE: Waste disposal at the Area 6 Hydrocarbon Landfill must have come into contact with petroleum hydrocarbons or coolants, such as: gasoline (no benzene, lead); jet fuel; diesel fuel; lubricants and hydraulics; kerosene; asphaltic petroleum hydrocarbon; and ethylene glycol.
Acceptable waste at any NTS landfill:
$\square$ Paper
$\square$ Rocks / unaltered geologic materials
Asphalt
$\bigotimes$ Metal
$\square$ Wood
$\square$ Soil
$\square$ Rubber (excluding tires)
Plastic $\square$ Wire $\square$ Cable
$\square$ Cloth
$\square$ Insulation (non-Asbestosform)

$\bigotimes$ Empty containers

$\square$ Demolition debris

Manufactured items: (swamp coolers, furniture, rugs, carpet, electronic components, PPE, etc.)
Additional waste accepted at the Area 23 Mercury Landfill: $\quad \square$ Office Waste
$\square$ Food Waste
Animal Carcasses
$\square$ Asbestos
Friable
Non-Friable (contact SWO if regulated load)
Quantity:

\section{Additional waste accepted at the Area 9 U10c Landfill:}

Light ballasts (contact SWO)

Drained automobiles and military vehicles

$\square$ Hydrocarbons (contact SWO)

Drained fuel filters (gas \& diesel)

Solid fractions from sand/oil/water

Other tires packaged within a B25 box

Additional waste accepted at the Area 6 Hydrocarbon Landfill:
$\square$ Septic sludge
$\square$ Rags
$\square$ Drained fuel filters (gas \& diesel)
Plants
Soil
$\square$ Sludge from sand/oil/water separators
$\square$ Crushed non-teme plated oil filters REQUIRED: WASTE GENERATOR SIGNATURE

Initials: (if initialed, no radiological clearance is necessary.)

The above mentioned waste was generated outside of a Controlled Waste Managem knowledge, does not contain radiological materials.

To the best of my knowledge, the waste described above contains only those mater site. I have verified this through the waste characterization method identified abov $\epsilon$ prohibited and allowable waste items. I have contacted Property Management and I is approved for disposal in the landfill.

Print Name: MIKE FLOYD

Signature:__/s/: Mike Floyd Date: $10 / 11 / 11$ Radiological Survey Release for Waste Disposal RCT Initials

This container/load meets the criteria for no

(2) added man-made radioactive material This container/load meets the criteria for Radcon Manual Table 4.2 release limits. This container/load is exempt from survey due tory cess knowledge and origin. SIGNATURE:/S/: Signature on File DATE $q$ od FRM-0646 (08/06)

Note: "Food waste, office trash and animal carcasses do not require a radiological clearance. Freon-containing appliances must have signed removal certification statement with Load Verification."

\section{SWO USE ONLY}

Load Weight (net from scale or estimate): $10 \mid 1111$ Signature of Certifier: /s/: Signature on File 
NSTec

Form

CERTIFICATE OF DISPOSAL

FRM-2217

(LOW LEVEL WASTE)

03/01/10

Rev. 01

Page 1 of 1

\section{Nevada Test Site}

This Certificate acknowledges that the following shipment(s) of waste have been disposed at the Nevada Test Site Radioactive Waste Management Complex.

\begin{tabular}{|l|l|l|l|}
\hline \multicolumn{1}{|c|}{ Shipment Number } & $\begin{array}{c}\text { Waste Stream } \\
\text { Identification \# }\end{array}$ & Package \# & Date of Disposal \\
\hline DPL11111 & LRY5LLFY11005 & 340000 & $08-03-2011$ \\
\hline & & & \\
\hline & & & \\
\hline & & & \\
\hline & & & \\
\hline & & & \\
\hline
\end{tabular}

This certification is provided as a courtesy to the waste generator for information purposes only.

/s/: Theresa Hale

WGS Signature

Waste Inspector

Title

/s/: Stephen E. Wolf

RWMIC Signature

Waste Speciclist
08-03-2011

Date

Date 
NSTec

Form

CERTIFICATE OF DISPOSAL

03/01/10

FRM-2217

(LOW LEVEL WASTE)

Rev. 01

Page 1 of 1

\section{Nevada Test Site}

This Certificate acknowledges that the following shipment(s) of waste have been disposed at the Nevada Test Site Radioactive Waste Management Complex.

\begin{tabular}{|l|l|l|l|}
\hline Shipment Number & $\begin{array}{c}\text { Waste Stream } \\
\text { Identification \# }\end{array}$ & \multicolumn{1}{|c|}{ Package \# } & Date of Disposal \\
\hline DPL12012 & LRY5LLFY99020 & 12 L018 (114154-20) & $1 / 30 / 11$ \\
\hline & & & \\
\hline & & & \\
\hline & & & \\
\hline & & & \\
\hline & & & \\
\hline & & & \\
\hline
\end{tabular}

This certification is provided as a courtesy to the waste generator for information purposes only.

/s/: Robert H. Zion

WGS Signature

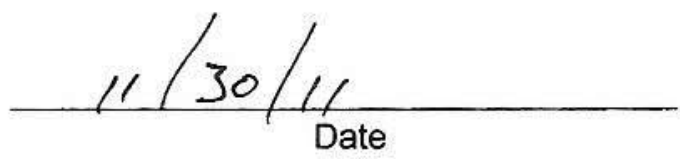

Waste Inspector

Title

/s/: Jon Tanaka

$\bar{R} W M C$ Signature

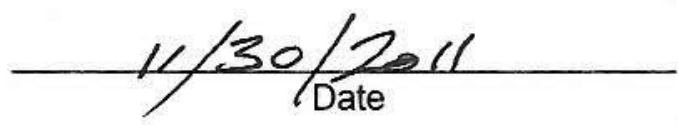

WASTE SPECIOLCST 


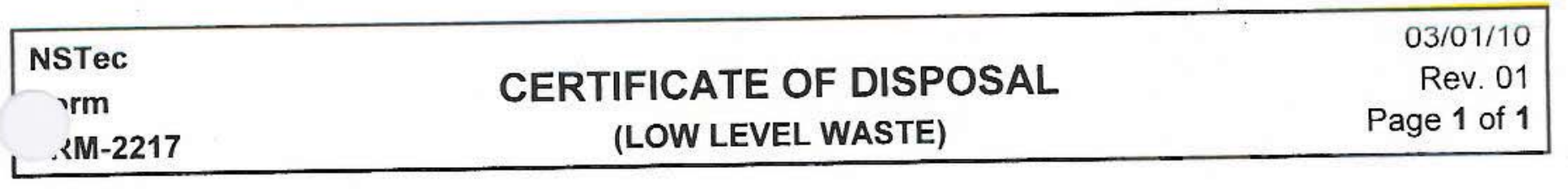

Nevada Test Site

This Certificate acknowledges that the following shipments) of waste have been disposed at the Nevada Test Site Radioactive Waste Management Complex.

\begin{tabular}{|l|l|l|l|}
\hline \multicolumn{1}{|c|}{$\begin{array}{c}\text { Waste Stream } \\
\text { Identification \# }\end{array}$} & \multicolumn{1}{|c|}{ Package \# } & Date of Disposal \\
\hline DPL12013 & LRY5LLFY11005 & 610006 & $1 / 4 / 12$ \\
\hline DPL12013 & LRY5LLFY11005 & 610023 & $1 / 4 / 12$ \\
\hline DPL12013 & LRY5LLFY11005 & 610025 & $1 / 4 / 12$ \\
\hline DPL12013 & LRY5LLFY11005 & 610019 & $1 / 4 / 12$ \\
\hline DPL12013 & LRY5LLFY11005 & 610018 & \\
\hline & & & \\
\hline & & & \\
\hline & & & \\
\hline
\end{tabular}

This certification is provided as a courtesy to the waste generator for information purposes only.

/s/: Robert H. Zion

WGS Signature

Waste Inspector

Title

/s/: Stephen E. Wolf

RWMC Signature
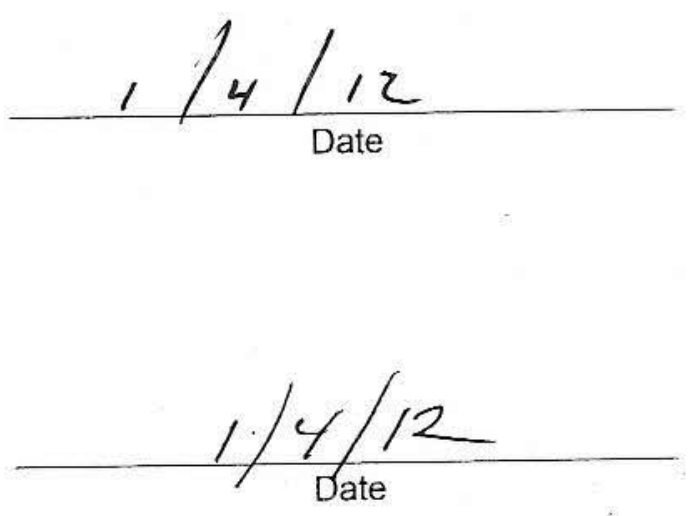

Waste Specliast

Title 


\begin{tabular}{|lcr|}
\hline NSTec & CERTIFICATE OF DISPOSAL & $03 / 01 / 10$ \\
Form & Rev. 01 \\
FRM-2217 & (LOW LEVEL WASTE) & Page $\mathbf{1}$ of $\mathbf{1}$ \\
\hline
\end{tabular}

Nevada Test Site

This Certificate acknowledges that the following shipments) of waste have been disposed at the Nevada Test Site Radioactive Waste Management Complex.

\begin{tabular}{|l|l|l|l|}
\hline \multicolumn{1}{|c|}{ Shipment Number } & $\begin{array}{c}\text { Waste Stream } \\
\text { Identification \# } \\
\text { DPL12014 }\end{array}$ & \multicolumn{1}{|c|}{ Package \# } & Date of Disposal \\
\hline LRY5LLFY11005 & 610002 & $1-5-12$ \\
\hline DPL12014 & LRY5LLFY11005 & 610004 & $1-5-12$ \\
\hline & LRY5LLFY11005 & 610016 & $1-5-12$ \\
\hline & & & \\
\hline & & & \\
\hline & & & \\
\hline & & & \\
\hline & & & \\
\hline
\end{tabular}

This certification is provided as a courtesy to the waste generator for information purposes only.

/s/: Robert H. Zion

WGS Sigńnature

Waste Inspector

Title

Is/: Stephen E. Wolf

RWMC Signature
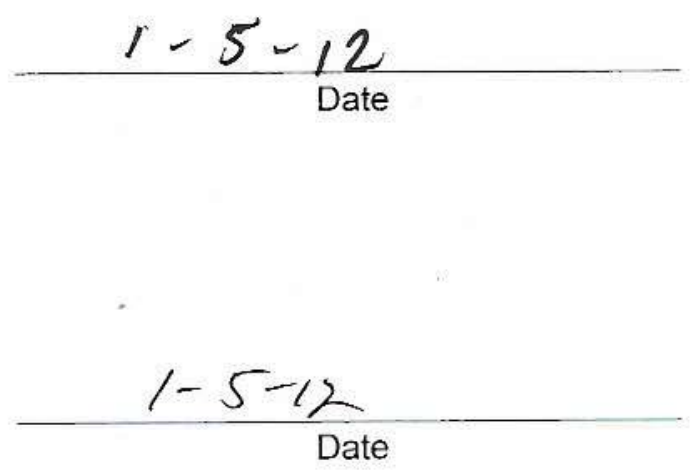

waste specialist

Title 
NSTec

Form

FRM-2217
CERTIFICATE OF DISPOSAL (LOW LEVEL WASTE)
03/01/10

Rev. 01

Page 1 of 1

Nevada Test Site

This Certificate acknowledges that the following shipments) of waste have been disposed at the Nevada Test Site Radioactive Waste Management Complex.

\begin{tabular}{|l|l|l|l|}
\hline Shipment Number & $\begin{array}{c}\text { Waste Stream } \\
\text { Identification \# }\end{array}$ & Package \# & Date of Disposal \\
\hline DPL12015 & LRY5LLFY11005 & 610020 & $1-5-12$ \\
\hline & & & \\
\hline & & & \\
\hline & & & \\
\hline & & & \\
\hline & & & \\
\hline & & & \\
\hline
\end{tabular}

This certification is provided as a courtesy to the waste generator for information purposes only.

/s/: Robert H. Zion

WGS Signature

Waste Inspector

Title

/s/: Stephen E. Wolf

RWMC Signature

$\frac{\text { Waste specialist }}{\text { Title }}$

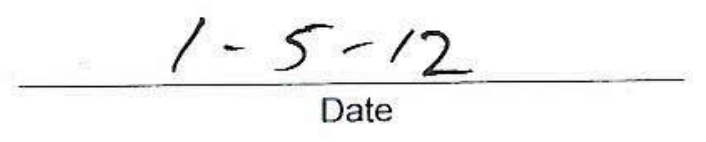

Date

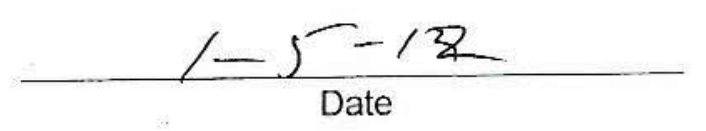


National Security Technologies "c

For U.S. Department of Energy Waste

Management

Nevada National Security Site - Zone 2

Mercury, NV 89023

EPA ID NV3890090001

This Certificate acknowledges that the following shipment(s) of manifested MIXED LOW. LEVEL waste have been disposed at the Nevada National Security Site Radioactive Waste Management Site.

\begin{tabular}{|c|c|c|c|c|}
\hline $\begin{array}{c}\text { Shipment } \\
\text { Number }\end{array}$ & $\begin{array}{c}\text { Uniform Hazardous } \\
\text { Waste Manifest Number }\end{array}$ & Date(s) of Disposal & Volume $\left.\mathrm{Ft}^{\mathbf{3}} \mathbf{( m}^{\mathbf{3}}\right)$ & Disposal Process \\
\hline DPM12002 & $000000012 \mathrm{N42}$ & $06 / 27 / 2012$ & $450.27(12.75)$ & Landfill \\
\hline DPM12003 & $000000012 \mathrm{~N} 43$ & $06 / 27 / 2012$ & $450.27(12.75)$ & Landfill \\
\hline DPM12004 & $000000012 \mathrm{~N} 44$ & $06 / 27 / 2012$ & $450.27(12.75)$ & Landfill \\
\hline DPM12005 & $000000012 \mathrm{~N} 45$ & $06 / 27 / 2012$ & $450.27(12.75)$ & Landfill \\
\hline DPM12006 & $000000012 \mathrm{~N} 46$ & $06 / 27 / 2012$ & $360.21(10.20)$ & Landfill \\
\hline & & & & \\
\hline & & & & \\
\hline
\end{tabular}

This certification is provided as a courtesy to the waste generator for information purposes only.

/s/: Rose C. Denton for Patrick Arnold

Signature

$\frac{7.2-2012}{\text { Date }}$

Program Manager, Radioactive Waste Program

Title

\section{Instructions:}

Shipment Number - enter shipment number from LWIS database.

Uniform Hazardous Waste Manifest Number - enter number from UHWM provided by generator.

Date of Disposal - enter date waste was placed in disposal cell.

Volume - enter shipment volume in cubic feet and equivalent cubic meters in parenthesis.

Disposal Process - enter Landfill. 
National Security Technologies "c

For U.S. Department of Energy Waste

Management

Nevada National Security Site - Zone 2

Mercury, NV 89023

EPA ID NV3890090001

This Certificate acknowledges that the following shipment(s) of manifested MIXED LOW- LEVEL waste have been disposed at the Nevada National Security Site Radioactive Waste Management Site.

\begin{tabular}{|c|c|c|c|c|}
\hline $\begin{array}{c}\text { Shipment } \\
\text { Number }\end{array}$ & $\begin{array}{c}\text { Uniform Hazardous } \\
\text { Waste Manifest Number }\end{array}$ & Date(s) of Disposal & Volume $\mathrm{Ft}^{3}\left(\mathbf{m}^{3}\right)$ & Disposal Process \\
\hline DPM12007 & $000000012 \mathrm{~N} 49$ & $07 / 31 / 2012$ & $128.19(3.63)$ & Landfill \\
\hline & & & & \\
\hline & & & & \\
\hline & & & & \\
\hline & & & & \\
\hline & & & & \\
\hline & & & & \\
\hline
\end{tabular}

This certification is provided as a courtesy to the waste generator for information purposes only.

/s/: P. M. Arnold

Signature

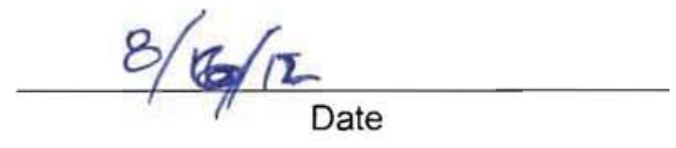

Program Manager, Radioactive Waste Program

Title

Instructions:

Shipment Number - enter shipment number from LWIS database.

Uniform Hazardous Waste Manifest Number - enter number from UHWM provided by generator.

Date of Disposal - enter date waste was placed in disposal cell.

Volume - enter shipment volume in cubic feet and equivalent cubic meters in parenthesis.

Disposal Process - enter Landfill. 
Please print or type. (Form designed for use on elite (12-pitch) typewriter.)

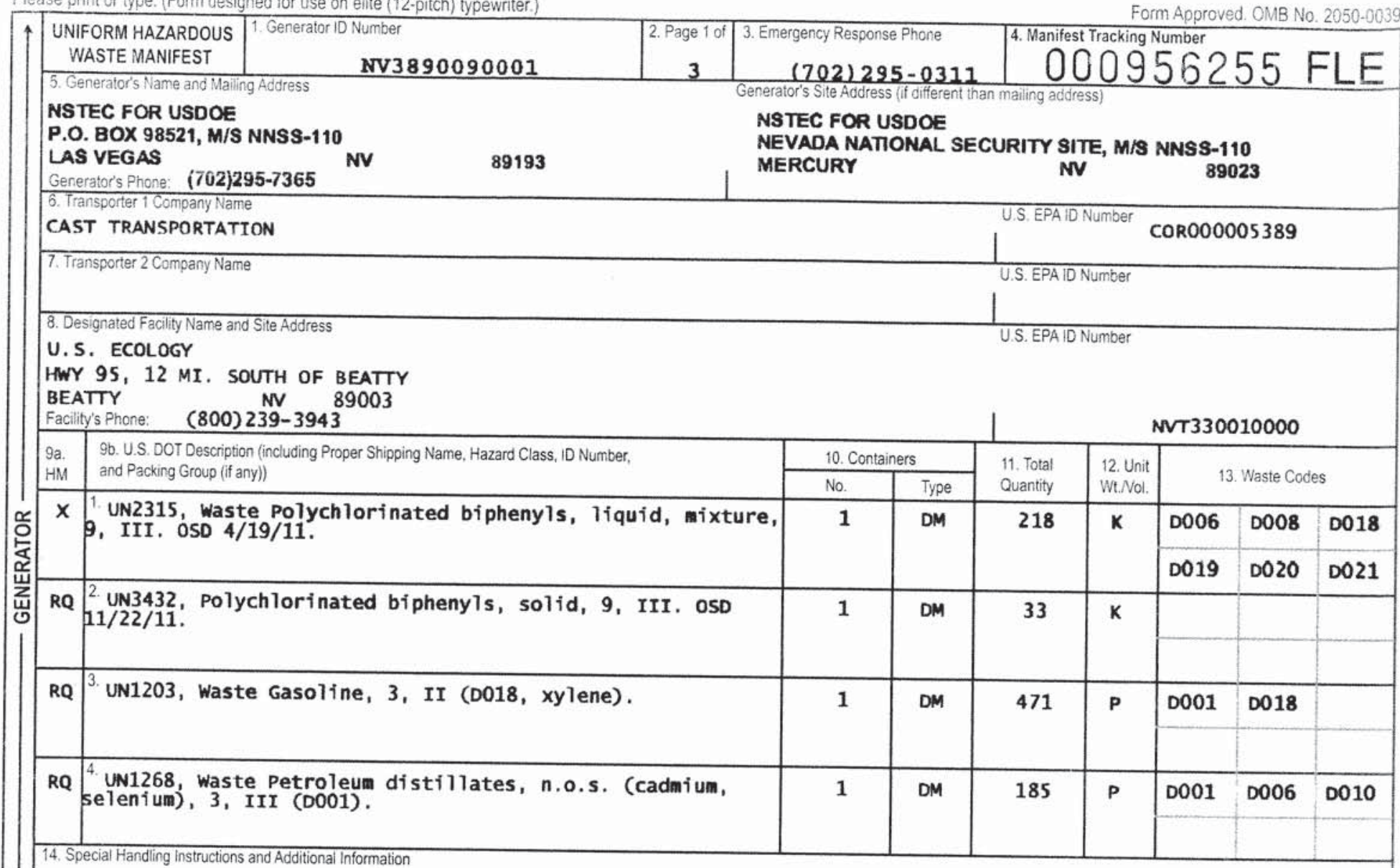

1. ERG 171;NS-NSS-11-0068;D022 THRU D043; \#070178976-0. 2. ERG $171 ; 12-0014 ; \# 13-1022$. 3. ERG $128 ; 11-0079 ; \# 13-9713$.
4. ERG $128 ; 12-0003 ; \# 13-0955$. LOAD \#12001.

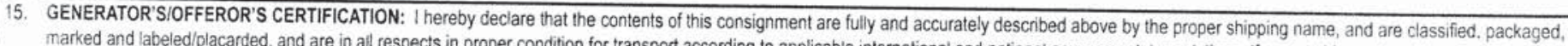

marked and labeled/placarded, and are in all respects in proper condition for transport according to applicable international and national governmental regulations. If export shipment and I am the Primary

Exporter, I certify that the contents of this consignment conform to the terms of the attached EPA Acknowledgment of Consent.

I certify that the waste minimization statement identified in 40 CFR 262.27(a) (if I am a large quantity generator) or (b) (if I am a small quantity generator) is Irue.

Generator's/Offeror's Printed/Typed Name

CIRILO CARLOS GONZALES

16. International Shipments
Transporter signature (for exports only):

ON BEHALF OF USDOE | /s/: Cirilo Carlos Gonzales

\section{$\square$ import to U.S.}

17. Transporter Acknowledgment of Receipt of Materials

Transporter 1 Printed/Typed Name

Transporter 2 Printed/Typed Name 1,12012125

18. Discrepancy

18a. Discrepancy Indication Space

$\square$ Quantity

$\square_{\text {Type }}$

$\square$ Export from U.S

$/ \mathrm{s} /$ :

Date leaving U.S

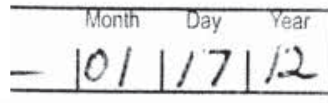

18b. Alternate Facility (or Generator)

Manifest Reference Number:

Facility's Phone:

18c. Signature of Alternate Facility (or Generator)

19. Hazardous Waste Report Management Method Codes (i.e., codes for hazardous waste treatment, disposal, and recycling systems)

\section{\begin{tabular}{l|l}
$H / 41$ & \\
\hline
\end{tabular}}

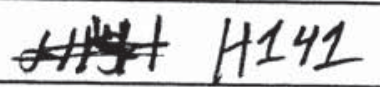

20. Designated Facility Owner or Operator: Cerrification of receipt of hazardous materials covered by the manifest except as noted in Item 18a 


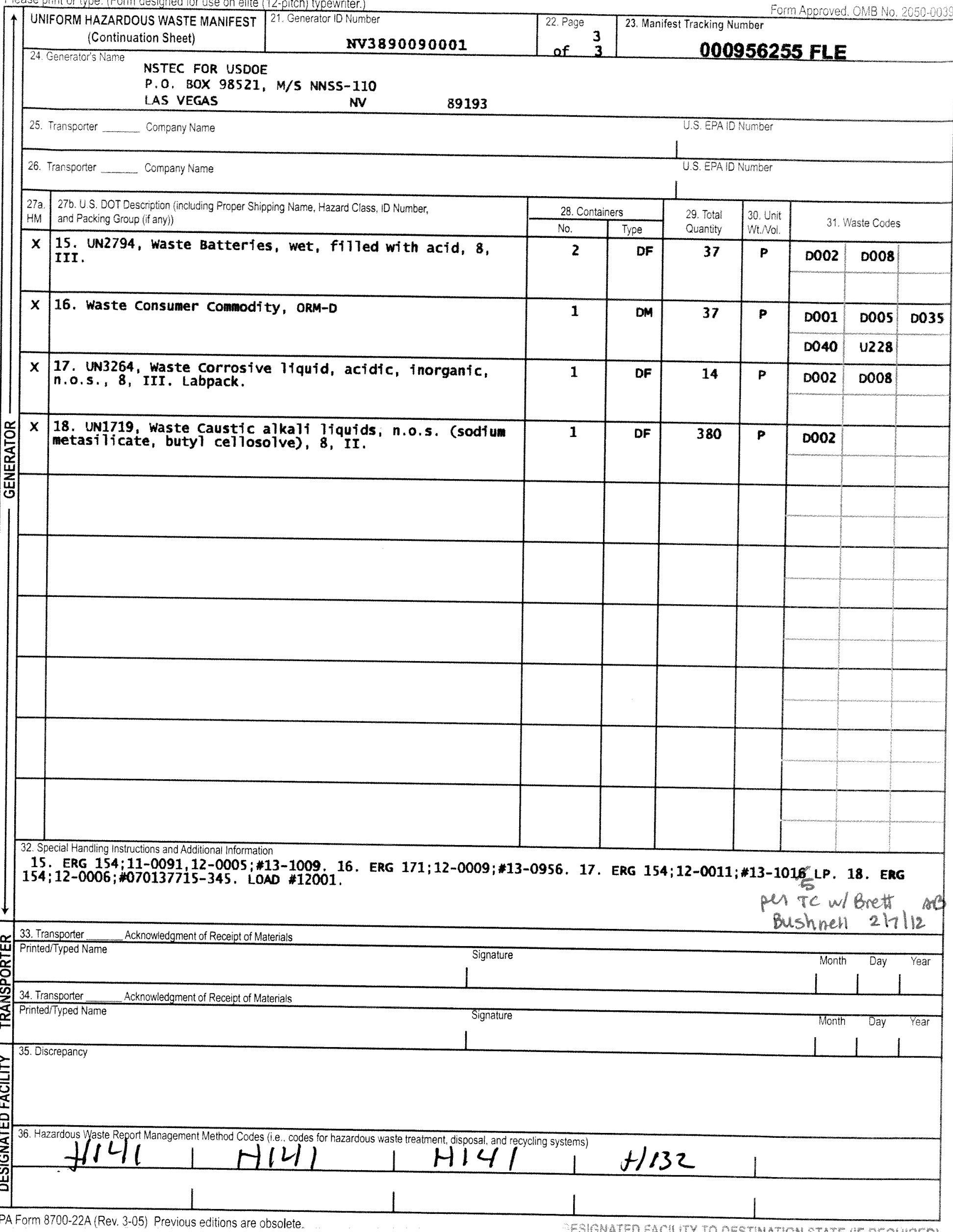


CAU 548 Closure Report

Section: Appendix B

Revision: 0

Date: August 2012

\section{THIS PAGE INTENTIONALLY LEFT BLANK}




\section{APPENDIX C \\ SECTORED HOUSEKEEPING SITE CLOSURE VERIFICATION FORMS}


CAU 548 Closure Report

Section: Appendix C

Revision: 0

Date: August 2012

\section{THIS PAGE INTENTIONALLY LEFT BLANK}




\section{Sectored Housekeeping Site Closure Verification Form}

Closure Verification Date: $07 / 14 / 2011$

CAU Number: 548

CAS Number: 09-99-02

CAS Description: Material Piles (2)

Sector Designation: Sector F

Housekeeping Site General Location: U-9av

Northing: 4,109,241.14 m (UTM, Zone 11) Easting: 585,632.62 m (UTM, Zone 11)

Latitude: 37.1274

Longitude: -116.0360

Coordinate/Elevation Data Obtained from: North American Datum, 1927

Site Access Route: Take Mercury Highway north to Rainier Mesa Road. Turn left (northwest) on Rainier Mesa Road and proceed to 2-03 Road. Turn right (north) on 2-03 Road and proceed 0.5 mile to 9-01 Road. Turn right (east) on 9-01 Road and proceed approximately 2.11 miles to Old Mercury Highway. Turn left (north) on Old Mercury Highway and proceed 0.4 mile to 9-V Road. Turn right (east) on 9-V Road and proceed 0.2 mile. The U9av Crater is on the right (south). The site is located approximately $100 \mathrm{ft}$ north of the U-9av Crater, just east of an elongated pit.

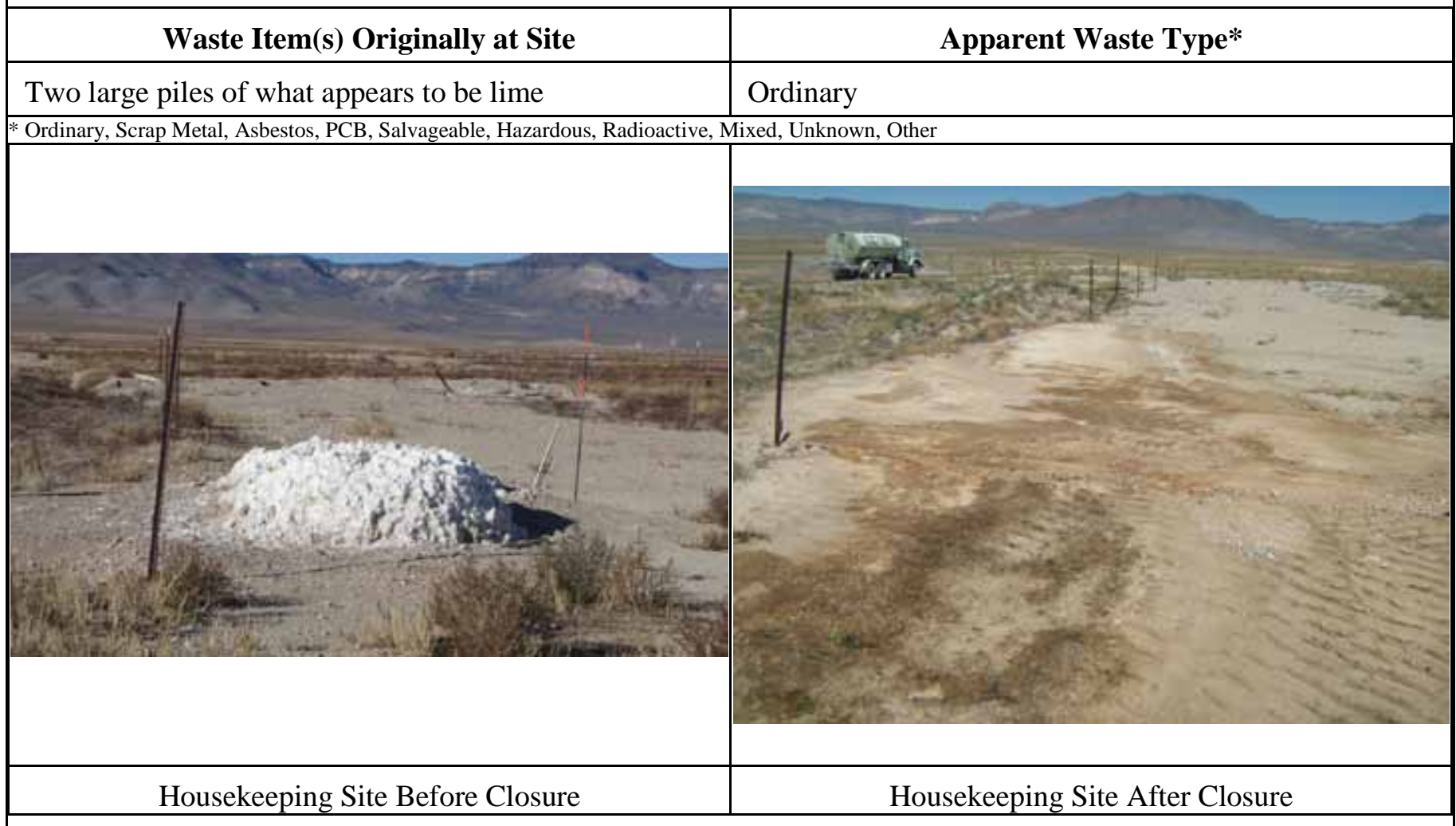

Current Site Description/Observations: The material pile was removed and disposed at the Area 9 U10c Sanitary Landfill.

X No Further Action Required at Housekeeping Site

Alissa Silvas

SIGNATURE APPROVED

06/06/2012

Corrective Action Coordinator/Designee

Signature

Date 


\section{Sectored Housekeeping Site Closure Verification Form}

Closure Verification Date: 10/06/2011

CAU Number: 548

CAS Number: 09-99-04

CAS Description: Wax, Paraffin

Sector Designation: Sector F

Housekeeping Site General Location: U-9av

Northing: 4,109,192.86 m (UTM, Zone 11) Easting: 585,667.3 m (UTM, Zone 11)

Latitude: 37.1270

Longitude: -116.0356

Coordinate/Elevation Data Obtained from: North American Datum, 1927

Site Access Route: Take Mercury Highway north to Rainier Mesa Road. Turn left (northwest) on Rainier Mesa Road and proceed to 2-03 Road. Turn right (north) on 2-03 Road and proceed 0.5 mile to 9-01 Road. Turn right (east) on 9-01 Road and proceed approximately 2.11 miles to Old Mercury Highway. Turn left (north) on Old Mercury Highway and proceed 0.4 mile to 9V Road. Turn right (east) on 9V Road and proceed 0.2 mile to the U-9av Crater on the right (south). The site is located near the northeast side of the U-9av Crater.

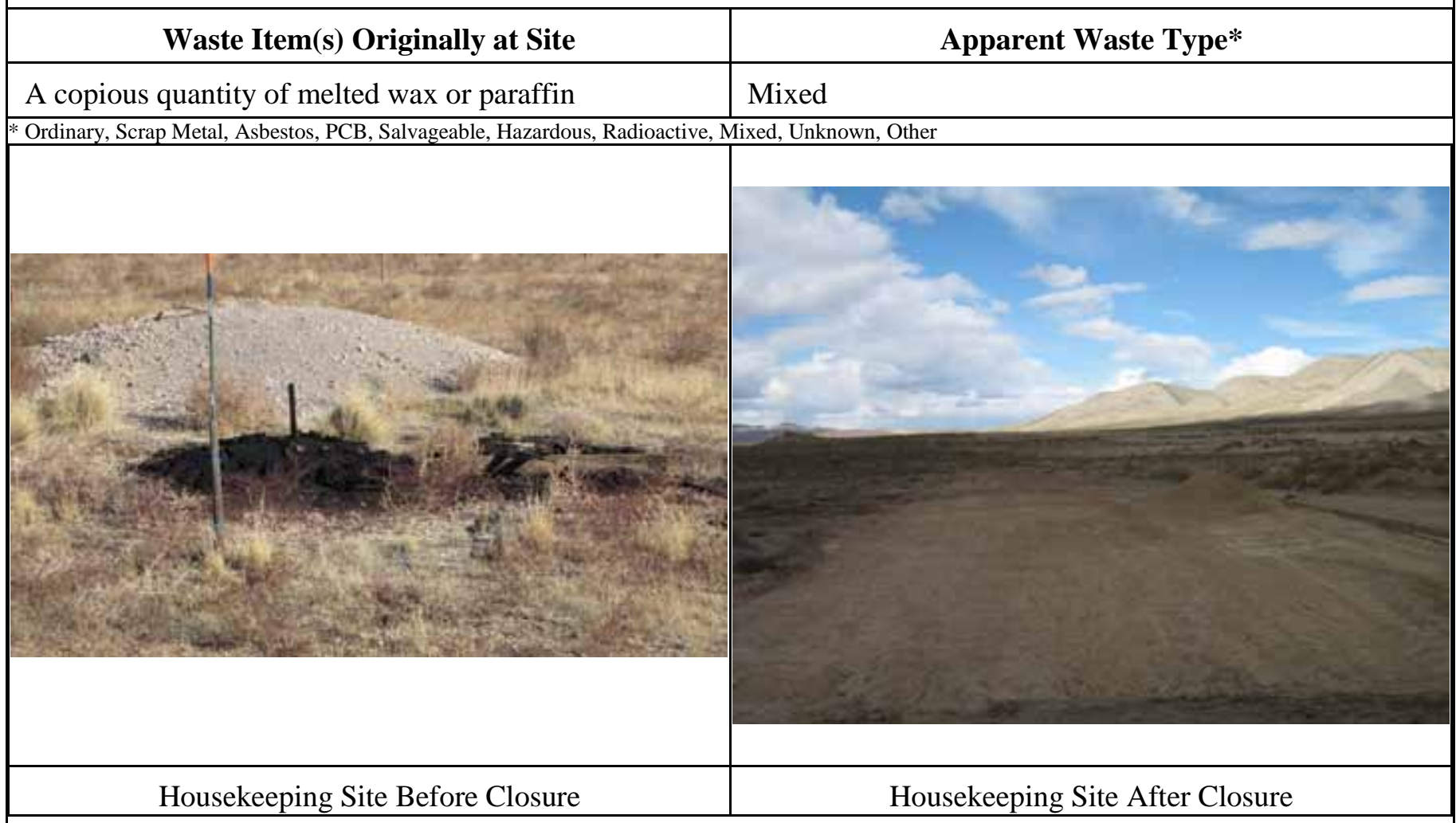

Current Site Description/Observations: The material pile and soil was removed, packaged in nine B-25 boxes, treated at an offsite treatment facility, and disposed as mixed waste at the Area 5 Radioactive Waste Management Site.

X No Further Action Required at Housekeeping Site

Alissa Silvas

SIGNATURE APPROVED

06/06/2012

Corrective Action Coordinator/Designee

Signature

Date 


\section{Sectored Housekeeping Site Closure Verification Form}

Closure Verification Date: $07 / 18 / 2011$

CAU Number: 548

CAS Number: 09-99-05

CAS Description: Asbestos, Vermiculite

Sector Designation: Sector F

Housekeeping Site General Location: U-9av

Northing: 4,109,192.68 m (UTM, Zone 11) Easting: 585,667.27 m (UTM, Zone 11)

Latitude: 37.1270

Longitude: -116.0356

Coordinate/Elevation Data Obtained from: North American Datum, 1927

Site Access Route: Take Mercury Highway north to Rainier Mesa Road. Turn left (northwest) on Rainier Mesa Road and proceed to 2-03 Road. Turn right (north) on 2-03 Road and proceed 0.5 mile to 9-01 Road. Turn right (east) on 9-01 Road and proceed approximately 2.11 miles to Old Mercury Highway. Turn left (north) on Old Mercury Highway and proceed 0.4 mile to 9V Road. Turn right (east) on 9V Road and proceed 0.2 mile to the U-9av Crater on the right (south). The site is located near the northeast side of the U-9av Crater.

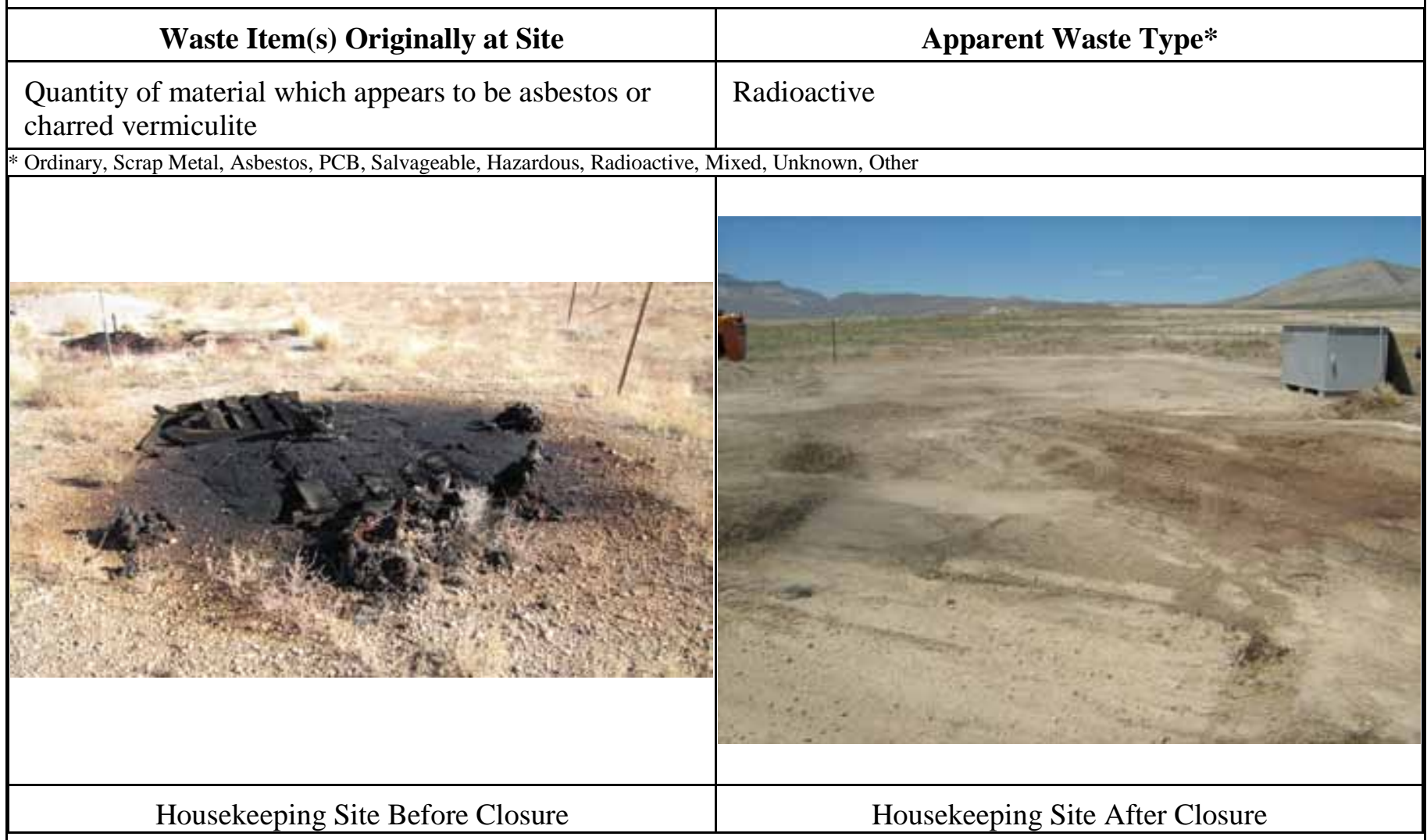

Current Site Description/Observations: The material pile was removed, packaged in one B-25 box, and disposed as low-level waste at the Area 5 Radioactive Waste Management Site.

X No Further Action Required at Housekeeping Site

Alissa Silvas

SIGNATURE APPROVED

06/06/2012

Corrective Action Coordinator/Designee

Signature

Date 


\section{Sectored Housekeeping Site Closure Verification Form}

Closure Verification Date: $07 / 14 / 2011$

CAU Number: 548

CAS Number: 09-99-07

CAS Description: Tar Spill

Sector Designation: Sector F

Housekeeping Site General Location: U-9 ITS V-26

Northing: 4,110,542.27 m (UTM, Zone 11) Easting: 585,569.85 m (UTM, Zone 11)

Latitude: 37.1392

Longitude: -116.0366

Coordinate/Elevation Data Obtained from: North American Datum, 1927

Site Access Route: Take Mercury Highway north to Rainier Mesa Road. Turn left (northwest) on Rainier Mesa Road and proceed to 2-03 Road. Turn right (north) on 2-03 Road and proceed 0.5 mile to 9-01 Road. Turn right (east) on 9-01 Road and proceed approximately 2.11 miles to Old Mercury Highway. Turn left (north) on Old Mercury Highway and proceed 1.15 miles to RSM 9L-23. Turn left (west) and travel cross country approximately $250 \mathrm{ft}$ to the south side of the U-9 ITS V-26 Crater. The spill is located on the south edge of the crater.

\begin{tabular}{|l|l|}
\hline \multicolumn{1}{|c|}{ Waste Item(s) Originally at Site } & \multicolumn{1}{c|}{ Apparent Waste Type* } \\
\hline Tar spill about $10^{\prime}$ x $5^{\prime}$ & Ordinary \\
\hline * Ordinary Scrap Metal, Asbestos, PCB, Salvageable Hazardous Radioactive, Mixed, Unknown Other \\
\hline
\end{tabular}

* Ordinary, Scrap Metal, Asbestos, PCB, Salvageable, Hazardous, Radioactive, Mixed, Unknown, Other

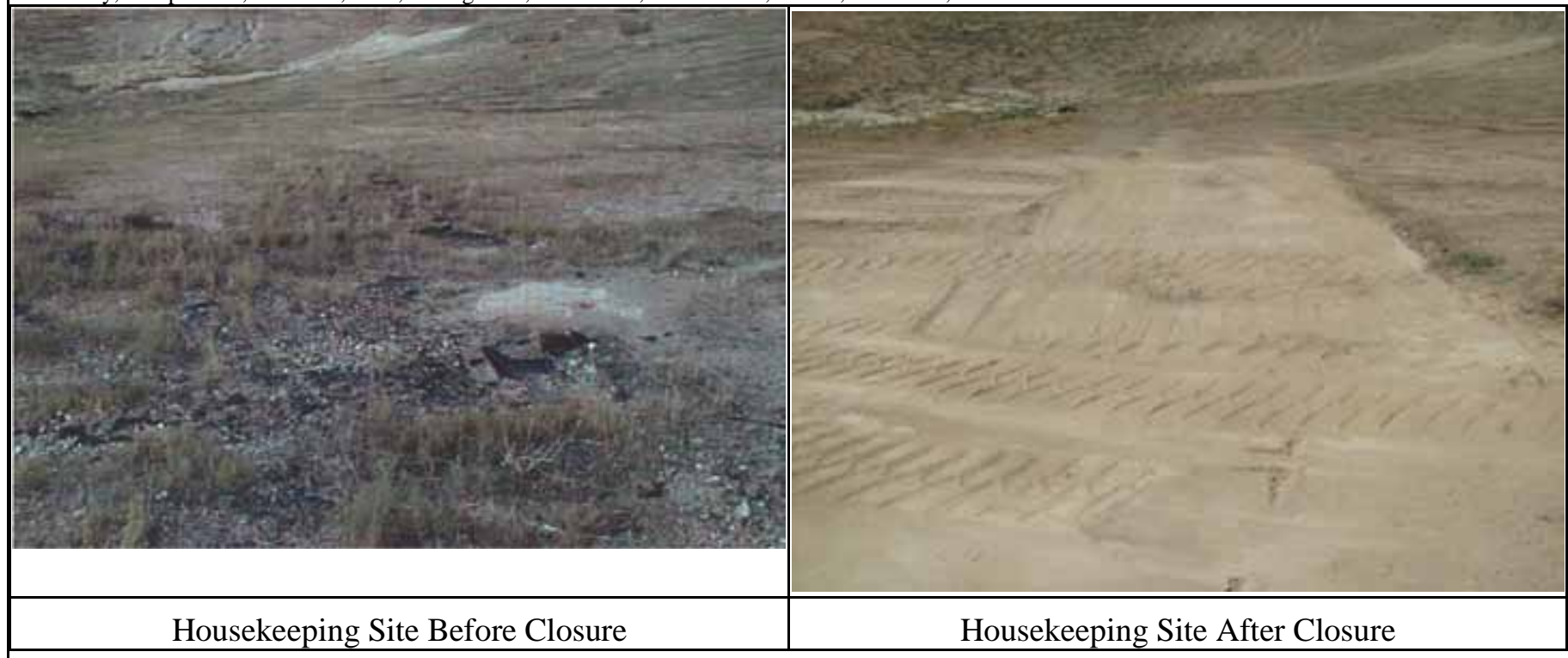

Current Site Description/Observations: The tar spill was removed and disposed at the Area 9 U10c Sanitary Landfill.

X No Further Action Required at Housekeeping Site

Alissa Silvas

Corrective Action Coordinator/Designee
SIGNATURE APPROVED

Signature
06/06/2012

Date 


\section{Sectored Housekeeping Site Closure Verification Form}

Closure Verification Date: $07 / 14 / 2011$

CAU Number: 548

CAS Number: $10-22-38$

CAS Description: Drum; Cable

Sector Designation: Sector F

Housekeeping Site General Location: Teapot Crater

Northing: 4,113,609 m (UTM, Zone 11) ～Easting: 584,830 m (UTM, Zone 11)

Latitude: 37.1669

Coordinate/Elevation Data Obtained from: North American Datum, 1927

Site Access Route: Take Mercury Highway north to Rainier Mesa Road. Turn left (northwest) onto Rainier Mesa Road and proceed to 2-07 Road. Turn right (east) and proceed to the Circle Road intersection. Turn left (north) on Circle Road and proceed 0.7 mile to 10-01 Road. Turn right (east) on 10-01 Road and proceed 1.0 mile. The site is $300 \mathrm{ft}$ and 200 degrees from the Teapot Crater.

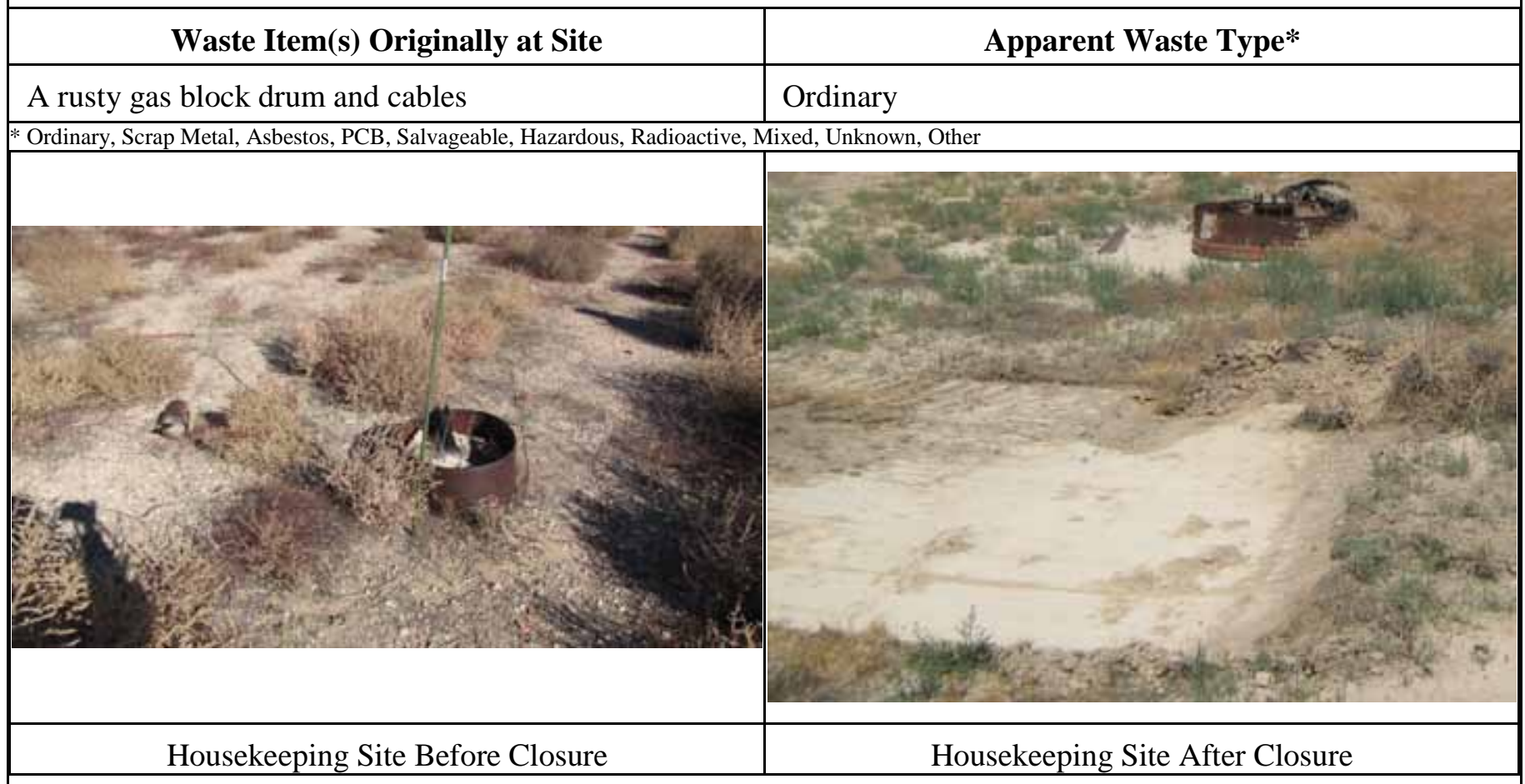

Current Site Description/Observations: The 55-gallon gas block drum, a small can, and wooden debris were removed and disposed at the Area 9 U10c Sanitary Landfill.

\section{No Further Action Required at Housekeeping Site}

Alissa Silvas

Corrective Action Coordinator/Designee
SIGNATURE APPROVED Signature
06/06/2012

Date




\section{Sectored Housekeeping Site Closure Verification Form}

Closure Verification Date: 11/09/2010

CAU Number: 548

CAS Number: 12-99-04

CAS Description: Epoxy Tar Spill

Sector Designation: Sector F

Housekeeping Site General Location: U-12g.03 CH 2

Northing: 4,114,146.65 m (UTM, Zone 11) Easting: 570,145.59 m (UTM, Zone 11)

Latitude: 37.1729

Longitude: -116.2099

Coordinate/Elevation Data Obtained from: North American Datum, 1927

Site Access Route: Take Mercury Highway north to Rainier Mesa Road. Turn left (northwest) on Rainier Mesa Road and proceed through the Area 12 Camp to Stockade Wash Road. Continue on Stockade Wash Road to R Road. Proceed on R Road to the fork in the road. Take the right fork onto P Road. Proceed to RSM 12P-5 and continue 0.05 mile downhill to the right. The site is approximately $300 \mathrm{ft}$ beyond this point.

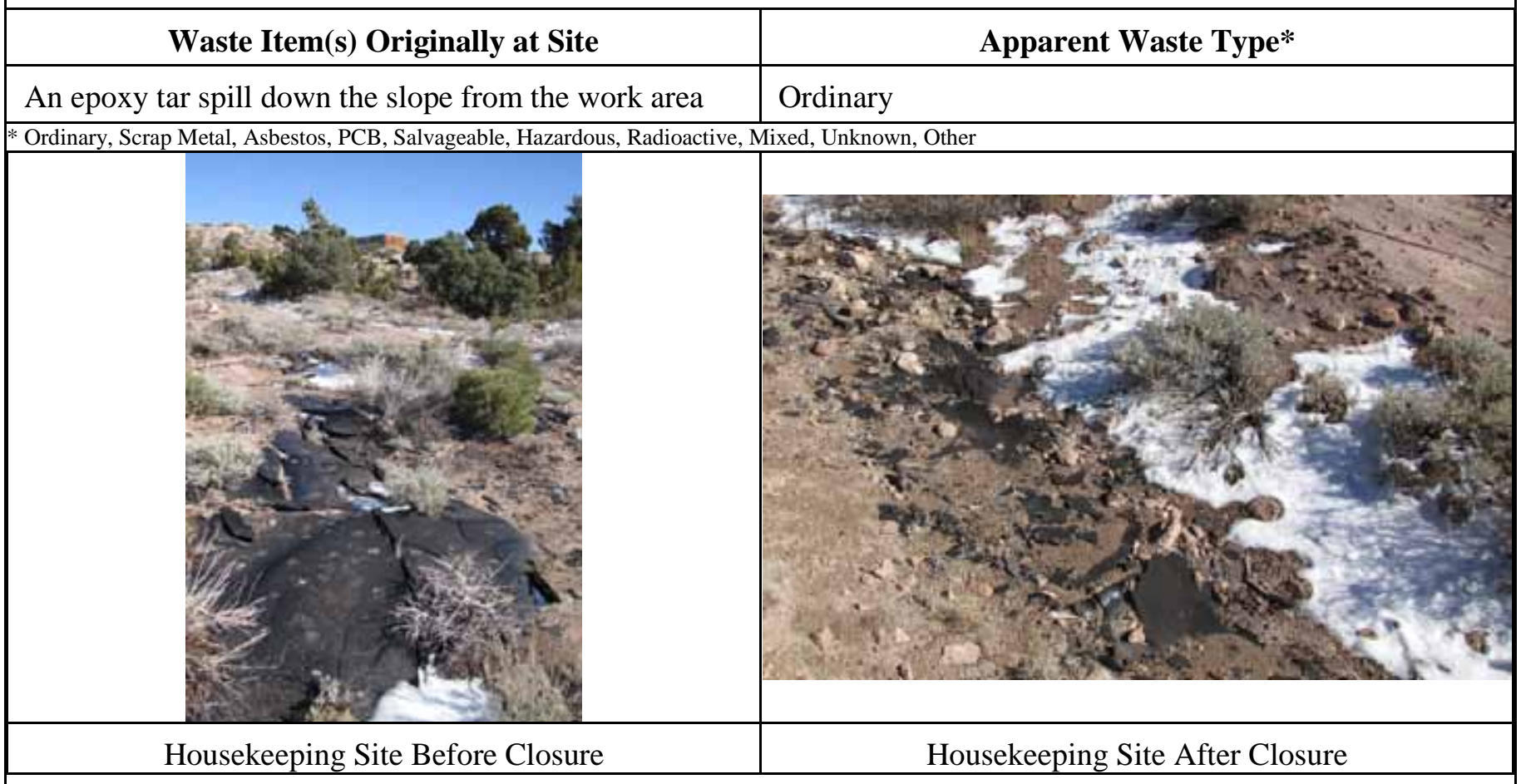

Current Site Description/Observations: The spill originally described at the site was determined to be a deteriorated 200-foot long drainage channel constructed to control water flow from a concrete pad. Due to the absence of contamination and the inability of heavy equipment to access the area, no further action was required, and no closure activities were performed.

X No Further Action Required at Housekeeping Site

Alissa Silvas Corrective Action Coordinator/Designee
SIGNATURE APPROVED Signature
06/06/2012

Date




\section{Sectored Housekeeping Site Closure Verification Form}

Closure Verification Date: 07/12/2011

CAU Number: 548

CAS Number: 12-99-08

CAS Description: Cement Spill

Sector Designation: Sector F

Housekeeping Site General Location: Area 12 Fire Station

Northing: 4,116,527.78 m (UTM, Zone 11) Easting: 574,495.89 m (UTM, Zone 11)

Latitude: 37.1941

Longitude: -116.1606

Coordinate/Elevation Data Obtained from: North American Datum, 1927

Site Access Route: Take Mercury Highway north to Rainier Mesa Road. Turn left (northwest) on Rainier Mesa Road and proceed to the Area 12 Camp. Turn right (north) on Logan Street and proceed approximately 0.15 mile. Turn left (west) onto Rainier Street and proceed approximately 0.2 mile to the fire station. The site is approximately $200 \mathrm{ft}$ north of the fire station, and $45 \mathrm{ft}$ (315 degrees) from the stop sign.

\begin{tabular}{|l|l|}
\hline \multicolumn{1}{|c|}{ Waste Item(s) Originally at Site } & \multicolumn{1}{c|}{ Apparent Waste Type* } \\
\hline Caustic cement spill & Ordinary \\
\hline * Ordinary Scap Metal Asestor
\end{tabular}

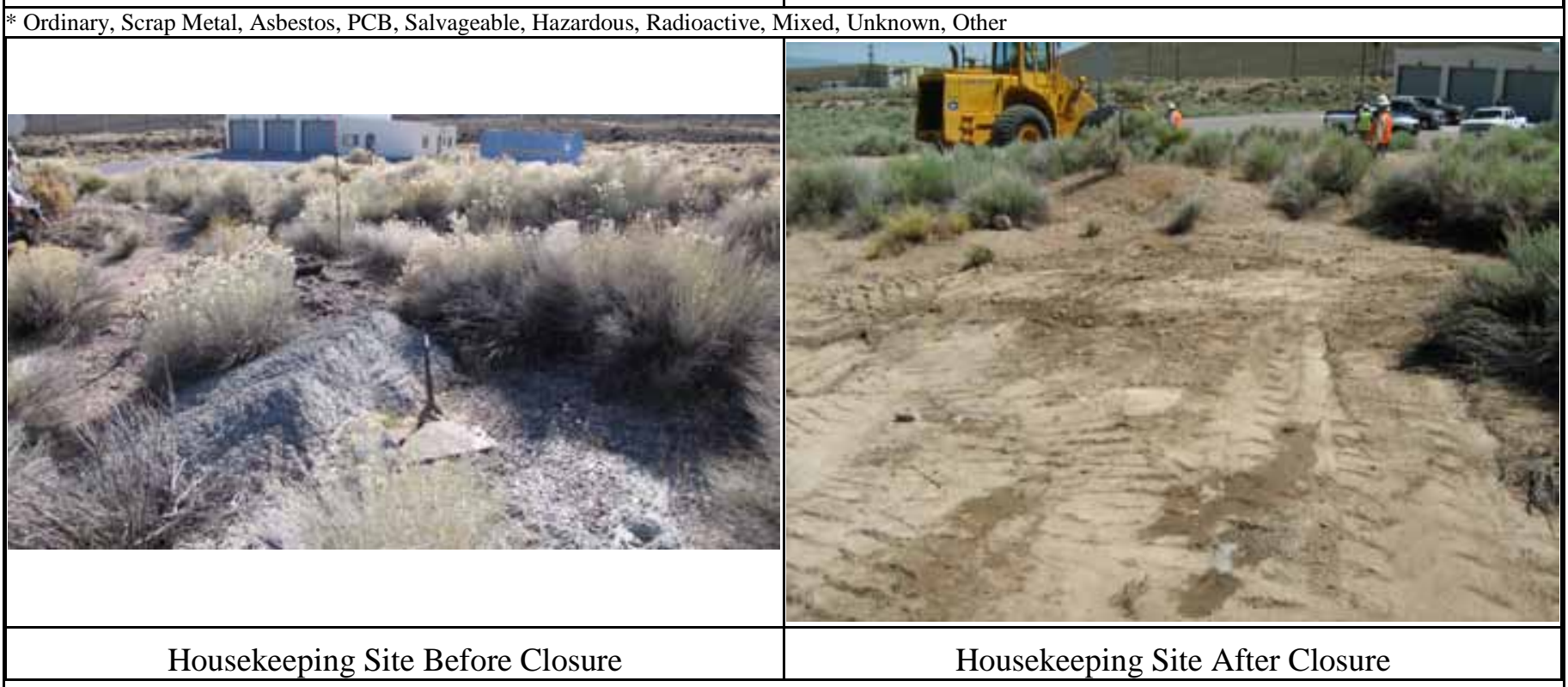

Current Site Description/Observations: The cement and asphalt piles were removed and disposed at the Area 9 U10c Sanitary Landfill.

X No Further Action Required at Housekeeping Site

Alissa Silvas

Corrective Action Coordinator/Designee
SIGNATURE APPROVED Signature
06/06/2012

Date 


\section{Sectored Housekeeping Site Closure Verification Form}

Closure Verification Date: 11/09/2010

CAU Number: 548

CAS Number: $18-14-01$

CAS Description: Transformers (3)

Sector Designation: Sector G

Housekeeping Site General Location: 17 Camp

Northing: 4,112,881 m (UTM, Zone 11) ～Easting: 565,332 m (UTM, Zone 11)

Latitude: 37.1619

Coordinate/Elevation Data Obtained from: North American Datum, 1927

Site Access Route: Take Mercury Highway (north) to Tippipah Highway. Turn left (northwest) onto Tippipah Highway and proceed to Pahute Mesa Road. Turn left (west) onto Pahute Mesa Road and proceed approximately 1.3 miles past the Stockade Wash Road to the intersection of Pahute Mesa Road and 18-B Road. Pahute C.P. (17 Camp) is on the southwest corner of the intersection. The site is on west side of the Area 17 Camp, within a chain-link (cyclone) fence.

\begin{tabular}{|c|c|}
\hline \multicolumn{1}{|c|}{ Waste Item(s) Originally at Site } & Apparent Waste Type* \\
\hline $\begin{array}{l}\text { There are three each transformers at the base of the } \\
\text { power poles (south, east, and west) providing power for } \\
\text { security lights at the Control Point Security Compound }\end{array}$ & Ordinary \\
\hline * Ordinary, Scrap Metal, Asbestos, PCB, Salvageable, Hazardous, Radioactive, Mixed, Unknown, Other \\
\hline Not available
\end{tabular}

Current Site Description/Observations: Three junction boxes containing wires were found. Transformers were not located at this site. No further action was required, and no closure activities were performed.

X No Further Action Required at Housekeeping Site

Alissa Silvas

Corrective Action Coordinator/Designee
SIGNATURE APPROVED Signature
06/06/2012

Date




\section{Sectored Housekeeping Site Closure Verification Form}

Closure Verification Date: 11/09/2010

CAU Number: 548

CAS Number: $19-22-01$

CAS Description: Drums

Sector Designation: Sector G

Housekeeping Site General Location: U-19ab

Northing: 4,122,784.25 m (UTM, Zone 11) Easting: 560,001.25 m (UTM, Zone 11)

Latitude: 37.2515

Longitude: -116.3243

Coordinate/Elevation Data Obtained from: North American Datum, 1927

Site Access Route: Take Mercury Highway north to Tippipah Highway. Turn left (west) on Tippipah Highway and proceed to Pahute Mesa Road. Turn left (west) onto a steep dirt road across from Dead Horse Flats Road. Travel approximately 0.65 mile to the U-19ab Crater.

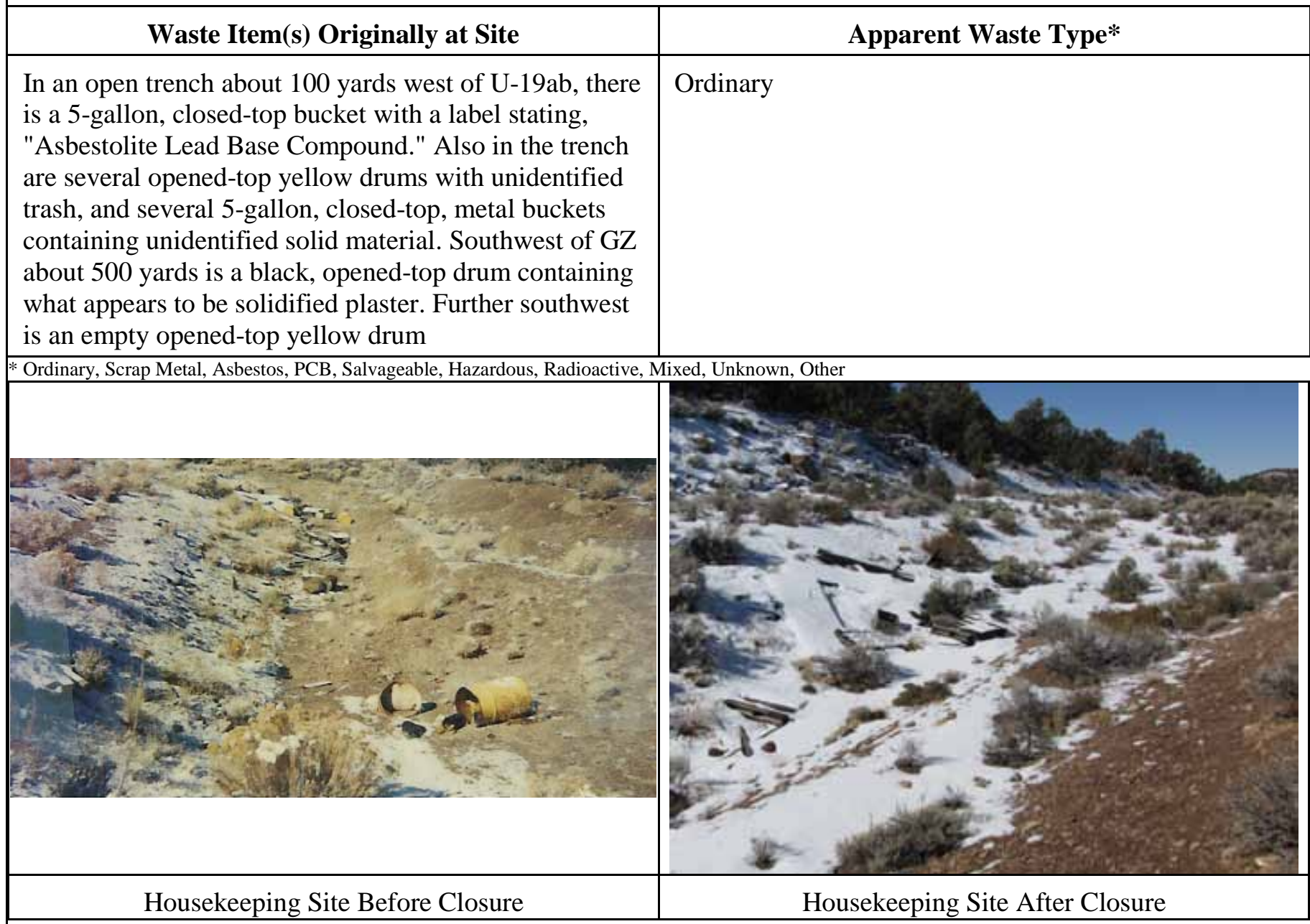

Current Site Description/Observations: The drums previously located at the site were not found and are assumed to have been removed. No further action was required, and no closure activities were performed.

X No Further Action Required at Housekeeping Site

Alissa Silvas

Corrective Action Coordinator/Designee
SIGNATURE APPROVED Signature
06/06/2012

Date 


\section{Sectored Housekeeping Site Closure Verification Form}

Closure Verification Date: 10/11/2011

CAU Number: 548

CAS Number: $20-22-07$

CAS Description: Drums (2)

Sector Designation: Sector G

Housekeeping Site General Location: U-20k

Northing: 4,125,933 m (UTM, Zone 11) ～Easting: 542,166.8 m (UTM, Zone 11)

Latitude: $37.2809 \quad$ Longitude: -116.5243

Coordinate/Elevation Data Obtained from: North American Datum, 1927

Site Access Route: Take Mercury Highway north to Tippipah Highway. Turn left (west) on Tippipah Highway and proceed to Pahute Mesa Road. Turn left (west) and on Pahute Mesa Road and proceed to Airport Road. Turn left (west) on Airport Road, which becomes Buckboard Mesa Road, and travel to Pahute Mesa Road. Turn left (northwest) on Pahute Mesa Road and travel 0.2 mile past RSM 20-J-29, to the U-20k access road. Take the dirt access road to the U-20k Crater on the south side of the road.

\begin{tabular}{|l|l|}
\hline \multicolumn{1}{|c|}{ Waste Item(s) Originally at Site } & \multicolumn{1}{c|}{ Apparent Waste Type* } \\
\hline Two drums & Ordinary, Radioactive, and Mixed \\
\hline * Ordinary, Scrap Metal, Asbestos, PCB, Salvageable, Hazardous, Radioactive, Mixed, Unknown, Other
\end{tabular}

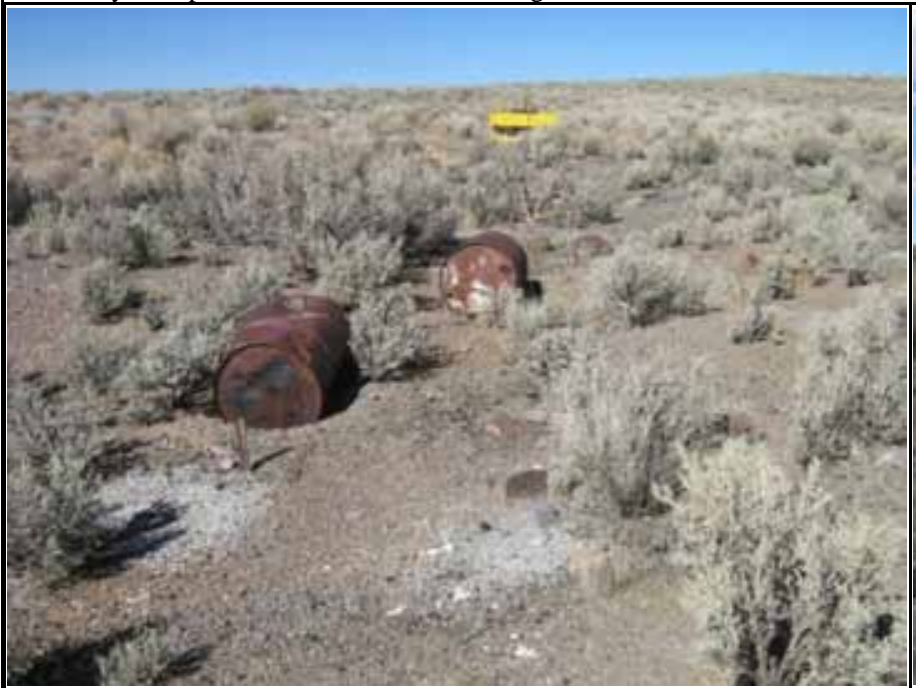

Housekeeping Site Before Closure

Housekeeping Site After Closure

Current Site Description/Observations: Five abandoned, empty 55-gallon drums were removed and disposed at the Area 9 U10c Sanitary Landfill. Two abandoned, empty 55-gallon drums were removed and disposed as low-level waste at the Area 5 Radioactive Waste Management Site. One lead acid battery was removed, packaged in a 55-gallon drum, treated at an offsite treatment facility, and disposed as mixed waste at the Area 5 Radioactive Waste Management Site. Tires were removed, packaged in one B-25 box, and disposed at the Area 9 U10c Sanitary Landfill.

$\mathrm{X}$ No Further Action Required at Housekeeping Site

Alissa Silvas Corrective Action Coordinator/Designee
SIGNATURE APPROVED Signature
06/06/2012

Date


CAU 548 Closure Report

Section: Library Distribution List

Revision: 0

Date: August 2012

\section{LIBRARY DISTRIBUTION LIST}


CAU 548 Closure Report

Section: Library Distribution List

Revision: 0

Date: August 2012

\section{THIS PAGE INTENTIONALLY LEFT BLANK}




\section{LIBRARY DISTRIBUTION LIST}

U.S. Department of Energy

National Nuclear Security Administration

Nevada Site Office

Technical Library

P.O. Box 98518, M/S 505

Las Vegas, NV 89193-8518

U.S. Department of Energy

Office of Scientific and Technical Information

P.O. Box 62

Oak Ridge, TN 37831-0062

Southern Nevada Public Reading Facility

c/o Nuclear Testing Archive

P.O. Box 98521, M/S 400

Las Vegas, NV 89193-8521

Manager, Northern Nevada FFACO

Public Reading Facility

c/o Nevada State Library \& Archives

Carson City, NV 89701-4285
1 (Uncontrolled, electronic copy)

1 (Uncontrolled, electronic copy)

2 (Uncontrolled, electronic copies)

1 (Uncontrolled, electronic copy) 
CAU 548 Closure Report

Section: Library Distribution List

Revision: 0

Date: August 2012

THIS PAGE INTENTIONALLY LEFT BLANK 